\title{
Nas matas com pose de reis: a representação de bandeirantes e a tradição da retratística monárquica européia*
}

\author{
Paulo César Garcez Marins**
}

\section{Resumo}

Este artigo dedica-se ao estudo da adoção e difusão de uma convenção pictórica - a pose monárquica consagrada em retratos de Hyacinthe Rigaud - em pinturas e esculturas do acervo do Museu Paulista que representam bandeirantes. Estas obras de arte, exemplos do chamado "gênero histórico", ingressaram no acervo do museu entre 1903 e 1922, período em que a instituição passou a acolher artefatos voltados à evocação e celebração do passado paulista como eixo condutor da história brasileira. As pinturas e esculturas serão compreendidas como parte dessa interpretação histórica, na medida em que constituíram uma solução visual capaz de dignificar e exaltar personagens do período sertanista, mediante uma forma de representação do corpo que demonstrava poder e solenidade.

\section{Palavras-chave}

pintura histórica, retrato, bandeirantes, Hyacinthe Rigaud, Benedito Calixto, Henrique Bernardelli.

* este artigo é resultado parcial do projeto de pesquisa "Imagens recriam a História”, dedicado à historicidade das representações artísticas presentes em pinturas e esculturas de temática histórica pertencentes sobretudo ao acervo do Museu Paulista da Universidade de São Paulo. Agradeço a leitura crítica da primeira versão deste texto realizada por John Manuel Monteiro e também à pesquisadora Mayra Tiemi Yonashiro Saito, pelo levantamento de documentos no Serviço de Documentação Textual e Iconográfica do Museu Paulista da USP (SVDHICO/MP).

*** historiador, doutor em História Social pela USP. Docente do Museu Paulista da USP. E-mail: pcgm@usp.br. 
revista do ieb n 44 p. 77-104 fev 2007

\title{
The royal pose in the jungle: the representation of the bandeirantes and the European monarchic's portrait tradition
}

\author{
Paulo César Garcez Marins
}

\begin{abstract}
This article is dedicated to the study of the adoption and diffusion of a pictorial convention - the royal pose established in the portraits by Hyacinthe Rigaud - seen in paintings and sculptures representing bandeirantes (paulistas' bushmen) that belong to the Museu Paulista. The Museum received these works of art, examples of the so called "historical painting", between 1903 and 1922, together with artifacts devoted to the evocation and celebration of the Paulista past as a guiding principle of the Brazilian History. The paintings and sculptures are understood as part of this interpretation, for they constituted a visual media capable of dignifying and praising characters of the sertanista (bushmen) period, mainly through the form they represented the body, showing both power and solemnity.
\end{abstract}

\section{Keywords}

history painting, portrait, bandeirantes, Hyacinthe Rigaud, Benedito Calixto, Henrique Bernardelli. 
0 sr. secretário de interior enviou ao Museu Paulista os quadros do pintor Benedito Calixto, encomendados e adquiridos pelo Estado: um representando Domingos Jorge Velho, o heroe dos Palmares e seu ajudante de ordens, e outro, Vicente Taques de Góes e Aranha, sargento-mór de Itu. ${ }^{1}$

Iniciou-se em 1903 a introdução de obras de arte com representações de bandeirantes no acervo do Museu Paulista, mediante a aquisição de uma tela que homenageava o sertanista que comandara a destruição do quilombo de Palmares. Esta aquisição, viabilizada por verba estadual, foi simultânea à emergência de uma interpretação histórica que apontava o fenômeno do sertanismo paulista como o elo decisivo entre a trajetória territorial do Brasil e de São Paulo, concepção esta que se consolidaria entre os historiadores ligados ao Instituto Histórico e Geográfico de São Paulo ao longo das três primeiras décadas do século XX. A tela Domingos Jorge Velho e o loco-tenente Antônio Fernandes de Abreu prestava-se a confirmar visualmente tal pretensão, na medida em que evocava o sertanista responsável pela destruição do mais inquietante quilombo surgido nas capitanias setentrionais e que constituíra ameaça à autoridade não apenas das elites açucareiras mas da própria coroa portuguesa. Homenageá-lo em tela e introduzir seu retrato imaginado num dos mais importantes museus brasileiros de então constituía uma iniciativa articulada ao pensamento historiográfico que preconizava a histórica supremacia dos paulistas tanto na delimitação das fronteiras externas quanto no apaziguamento, e submissão, das tensões internas.

Benedito Calixto, autor da pintura, utilizou para a composição formal do protagonista uma pose característica dos reis franceses da dinastia Bourbon, inaugurada por Hyacinthe Rigaud nos célebres retratos em que representara a majestade monárquica de Luís XIV. Esta solução pictórica adotada por Calixto ligava-se à necessidade de conferir ao retratado a maior dignidade possível, de maneira a evidenciar seu caráter altivo, atributo daquele que passava ser compreendido como um dos heróis da saga histórica simultaneamente paulista e brasileira.

A pose monárquica, que ganhara uma mediação decisiva em terras brasileiras a partir do retrato de D. João VI realizado por Jean-Baptiste Debret em 1817, hoje pertencente ao acervo do Museu Nacional de Belas Artes, foi repetida várias vezes em outras pinturas e esculturas relativas a bandeirantes produ-

1 MUSEU PAULISTA. SVDHICO. O Estado de São Paulo, Seção Notas e Informações, São Paulo, 05 mar. 1903. 
zidas nas primeiras décadas do século XX. Henrique Bernardelli, Nicolla Rollo, Van Emelen e Luigi Brizzolara realizaram pinturas e esculturas de gênero histórico em que a pose foi utilizada, numa repetição que acabou por consagrá-la como uma das mais importantes formas de representação e dignificação dos antigos sertanistas paulistas.

Este artigo procura documentar a emergência dessa solução pictórica no âmbito da produção de obras de arte demandadas pelo Museu Paulista, ao mesmo tempo em que compreende a exposição destas, sobretudo durante a gestão de Affonso d'Escragnole Taunay (1917-1945), como um procedimento de comunicação com o público visitante que almejava a formação de uma cultura visual capaz de consagrar os bandeirantes como heróis da história e da formação territorial brasileira ${ }^{2}$.

\section{0 trânsito de uma convenção pictórica}

Em artigo recente, Elaine Dias observou como a produção de retratos de João VI realizada por Jean-Baptiste Debret, durante sua estadia no Brasil, reelaborara a tradição da retratística Bourbon derivada da pintura Luís XIV em indumentária real,

2 Sobre o papel pedagógico das obras de arte encomendadas durante a gestão Taunay, várias delas com representações de bandeirantes, ver: MENESES, Ulpiano Toledo Bezerra de. O Salão Nobre do Museu Paulista e o teatro da História. In: ÀS MARGENS do Ipiranga, 1890-1990: catálogo de exposição. São Paulo: Museu Paulista/USP, 1990. CARVALHO, Vânia Carneiro de; LIMA, Solange Ferraz de. São Paulo antigo, uma encomenda da modernidade: as fotografias de Militão nas pinturas do Museu Paulista. Anais do Museu Paulista - História e Cultura Material, n. 1, p. 147-178, 1993. BREFE, Ana Claudia Fonseca. O Museu Paulista: Affonso de Taunay e a memória nacional, 19171945. São Paulo: Editora Unesp; Museu Paulista, 2005. CHIARELLI, Tadeu. Anotações sobre arte e história no Museu Paulista. In: FABRIS, Annateresa (Org.). Arte \&t politica: algumas possibilidades de leitura. Belo Horizonte: C/ Arte; São Paulo: Fapesp, 1998. p. 21-46. CHRISTO, Maraliz de Castro Vieira. Bandeirantes na contramão da História: um estudo iconográfico. Projeto História, São Paulo, 24, p. 307-335, jun. 2002. MAKINO, Miyoko. A ornamentação alegórica. In: WITTER, José Sebastião (Ed.); BARBUY, Heloisa (Org.). Museu Paulista, um monumento no Ipiranga. São Paulo: FIESP/CIESP/SESI/ SENAI/IRS, 1997. MAKINO, Miyoko. Ornamentação do Museu Paulista para o Primeiro Centenário: construção de identidade nacional na década de 1920. Anais do Museu Paulista - História e Cultura Material, São Paulo, n.10/11, p. 167-195, 2002-2003. MATTOS, Cláudia Valladão de. Da palavra à imagem: sobre o programa decorativo de Affonso Taunay para o Museu Paulista. Anais do Museu Paulista - História e Cultura Material, São Paulo, n. 6/7, p. 123-145, 2003. OLIVEIRA, Cecília Helena de Salles. Museu Paulista: espaço de evocação do passado e reflexão sobre a história. Anais do Museu Paulista - História e Cultura Material, São Paulo, n.10/11, p. 105-126, 2002-2003. 
realizada por Hyacinthe Rigaud em $1701^{3}$. Já no primeiro retrato de João VI, um estudo em óleo de 1817, Debret mimetizava o Rei-Sol e o padrão de representação régia do Antigo Regime, com a mão direita portando o cetro apoiado em uma almofada e o braço esquerdo sustentado na cintura. 0 trono, colunas e reposteiros compunham o cenário e reforçavam a aparência solene do retratado. Em oposição a este retrato a óleo e àquele, em gravura, que integra o terceiro volume da Viagem pitoresca e histórica ao Brasil, Debret utilizou, neste mesmo volume, um outro padrão para o retrato de Pedro I, já pautado pelos códigos instaurados por Jacques-Louis David ao retratar Napoleão I em pose corporal bem diversa daquela que marcara os retratos dos reis Bourbon ${ }^{4}$.

Os retratos de João VI realizados por Debret eram acessíveis a Benedito Calixto por meio de reproduções ou mediante a observação de exemplares da Viagem pitoresca, impressa em Paris na década de 1830. Mas as matrizes formais destes retratos também puderam certamente ser contempladas pelo pintor paulista, já que ele permanecera em Paris como estudante durante 1883 e 1884. Pode-se atribuir a este curto período de estudos a familiarização de Calixto com a tradição de retratos burbônicos que seria retomada em 1903, o que o capacitaria a um segundo transporte do modelo ao Brasil, décadas depois de Debret ${ }^{5}$.

As poucas referências existentes sobre sua formação em Paris indicam a passagem pelo ateliê de Jean François Raffaëlli e também pela Académie Julian - esta, célebre por ater-se à formação com base no modelo vivo e no estudo meticuloso da pose corporal, característica do sistema acadêmico francês oitocentista, além de estimular o conhecimento dos mestres anteriores por meio da observação e cópia de suas telas.

Existem ainda menções a visitas suas a Versailles e ao Louvre, locais em que se depositava a maior parte dos retratos de corte produzidos sob os Luíses. Tais visitas teriam permitido a contemplação de muitas telas em que era visível o cânone de seus retratos e que possivelmente o inspirariam vinte anos depois,

3 MUSEU DO LOUVRE (Paris). RMN 176791.

4 DIAS, Elaine. A representação da realeza no Brasil: uma análise dos retratos de D. João VI e D. Pedro I, de Jean-Baptiste Debret. Anais do Museu Paulista - História e Cultura Material, São Paulo, v. 14, n. 1, p. 243-261, jan.-jun. 2006.

5 As informações sobre a estadia de Benedito Calixto na França foram retiradas de: ALVES, Caleb Faria. Benedito Calixto e a construção do imaginário republicano. Bauru: Edusc, 2003. p. 87-132. Sobre a passagem de artistas brasileiros na Académie Julian e seus procedimentos de ensino, ver também: SIMIONI, Ana Paula Cavalcanti. A viagem a Paris de artistas brasileiros no final do século XIX. Tempo Social, São Paulo, v. 17, p. 343-366, jun. 2005. 
quando recebeu a incumbência de conceber um retrato imaginado de um paulista em fins do século XVII. A pose majestática utilizada por Calixto foi um artifício para caracterizar Domingos Jorge Velho como um "maior", e sua memória certamente recorreu aos retratos que pudera observar na França.

A pose monárquica bourbônica, tornada uma convenção a partir do referido retrato de Luís XVI realizado por Rigaud, foi um dos modelos mais contundentes da retratística do Antigo Regime, e esteve difundido nas cortes européias devido à supremacia artística francesa durante o século XVIII, bem como aos numerosos retratos enviados como presente e que se integrariam a essas coleções estrangeiras. A origem desta pose como representação real era, contudo, alheia à França, pois remontava a cerca de 1635, quando Van Dyck realizara o retrato de Carlos I, hoje pertencente ao Museu do Louvre ${ }^{6}$. Neste retrato, em que o soberano britânico está postado próximo a seu cavalo, o pintor flamengo utilizou uma pose característica dos retratos das elites flamengas e holandesas, em que um cotovelo é apontado para o espectador ${ }^{7}$.

Hyacinthe Rigaud, o mais importante retratista da corte de Luís XIV na passagem entre os séculos XVII e XVIII, retomou a solução pictórica de Van Dyck suavizando a direção do cotovelo para a lateral do corpo e mantendo o braço estendido com apoio. Dois de seus retratos do Rei Sol que utilizam esta pose - Luís XIV

6 Refiro-me a O rei na caçada (Le Roi à la chasse, RMN178653 / INV1236), pertencente a coleções reais francesas desde 1775, quando Luís XVI adquiriu a tela de Mme. Du Barry. A tela saiu da Inglaterra ainda no século XVII, e sua presença na França já está documentada antes de 1738, segundo informa a base de dados do Museu do Louvre. Embora esta tela seja sempre lembrada como o modelo de Hyacinthe Rigaud, devido ao soberano empunhar um bastão com a mão direita, apontado para o solo (o que lembra o segurar do cetro francês por Luís XIV), podemos apontar como outra eventual referência para Rigaud a tela de Van Dyck denominada Carlos I em traje de aparato, realizada em 1636. Para imagens das telas ver: BROWN, Christopher; VLIEGHE, Hans. Antoine van Dyck, 1599-1641. Gent: Ludion; Paris: Flammarion, 1999. p. 32, 304-5.

7 Entre os exemplos desta pose de cotovelo nas obras de van Dyck estão os retratos James Stuart, duque de Lennox e de Richmond, 1633-1634; O príncipe Carlos Luís, eleitor do Palatinado, e seu irmão, o príncipe Rupert do Palatinado, 1637; George, Lord Digby, e William, Loerd Russel, c.1637, Lord John Stuart e seu irmão Lord Bernard Stuart, c.1638, e o retrato, quando crianças, de George Villiers, segundo filho do duque de Buckingham, e seu irmão Lord Francis Villiers, 1635. BROWN, Christopher; VLIEGHE, Hans. Antoine van Dyck, 15991641. Gent: Ludion; Paris: Flammarion, 1999. p. 257-9, 312-3, 310-1, 320-1, 296. Sobre a tradição da pintura holandesa de afirmação de masculinidade mediante a pose do cotovelo dobrado, presente em telas de van der Maes, Hals, van Hoogstraten e Ferdinand Bol, ver: SPICER, Joaneath. The Renaissance elbow. In: BREMMER, Jan; ROODENBURG, Herman. A cultural history of gesture. Ithaca: Cornell University Press, 1992. p.84-128. 
em armadura e Luís XIV em indumentária real - sintetizam os principais modelos bourbônicos de representação com corpo em pé, atributo monárquico ou de grandes chefes militares ${ }^{8}$.

Em 1694, Rigaud pintou Luis XIV em armadura (Fig. 1), hoje pertencente ao Museu do Prado, em que a figura do rei, que está ao ar livre, repousa a mão direita, segurando o bastão de comando militar, sob um capacete, enquanto o braço esquerdo permanece flexionado e apoiado na cintura. Esta pose segue em linhas gerais o retrato de Monsieur, Philippe d'Orléans, duque de Chartres (o irmão do rei), feito por Rigaud em 1689, e também o de Anne-Jules de Noailles, conde de Ayen, marechal de França e vice-rei da Catalunha, de $1691^{9}$.

Luís XIV em armadura, embora muito menos célebre que Luis XIV em indumentária real, de 1701, foi base para inúmeros outros retratos de membros da realeza e nobreza em armadura, quando se quis enfatizar a condição masculina belingerante do retratado. São exemplos de sua difusão os retratos pintados por Rigaud de Frédéric-Auguste II, príncipe da Saxônia e futuro rei da Polônia, de 1715, de Louis-Antoine de Pardaillan de Gondrin, duque d'Antin, de 1708-1724, de Konrad Detlef, conde de Dehn, de 1723, e do Principe Joseph Wenzel Von Liechtestein, de $1740^{10}$.

Vários retratos dos Bourbon executados no século XVIII seguiram esta solução de pose em armadura, como o do príncipe Luís de França, le Grand Dauphin, de pintor desconhecido, os de Luís XV, realizados por J.B. Van Loo e por C.A. Van Loo, ou mesmo Louis de Bourbon-Condé, conde de Clermont, retratado por Drouais em 1771 sem armadura, mas com traje oficial do exército real ${ }^{11}$.

0 retrato em armadura de Luís XIV não pôde ser conhecido pessoalmente por Calixto, dado encontrar-se na Espanha, mas algumas destas últimas telas que o utilizaram como modelo podiam ser vistas em Versailles. Já a versão em indumentária real foi certamente contemplada pelo pintor paulista, assim como vários dos outros retratos nela inspirados, pois localizavam-se desde o século XIX nas galerias do Louvre e sobretudo nos aposentos de Versailles.

8 Os retratos pertencem respectivamente ao Museu do Prado e ao Museu do Louvre (RMN176791 / INV7492).

9 Para reproduções das telas mencionadas, consultar: PERREAU, Stéphan. Hyacinthe Rigaud: le peintre des rois. Montpellier: Les Presses du Languedoc, 2004. p. 87, 33, 48.

10 PERREAU, Stéphan. Hyacinthe Rigaud: le peintre des rois. Montpellier: Les Presses du Languedoc, 2004. p. 209, 197, 61, 196.

11 RMN167176 / MV3553; RMN14654 / MV6942; RMN178752 / MV3751; RMN166418 / MV3760. Disponível em: www.photo.rmn.fr. 
Rigaud estabeleceu em Luís XIV em indumentária real, de 1701 (Fig.2), o padrão definitivo de representação real, célebre não apenas pela pose, mas pela suntuosa indumentária, em que se destaca o manto de arminho e veludo azul fleurdelisé. Esta pintura, em que o rei é representado em frente ao trono, apoiando seu braço direito no cetro invertido que se mimetiza num bastão de apoio $^{12}$, foi inúmeras vezes reproduzida por ordem da Coroa, que destinou suas cópias para envio a corte européias ou órgãos administrativos na própria França. 0 retrato ganhou também versão oficial em gravura, realizada por Pierre Devret entre 1714 e $1715^{13}$. Sua difusão garantiu a consolidação da pose como um padrão ao mesmo tempo de majestade e masculinidade, muito embora as sensibilidades atuais, marcadas pela discrição oitocentista, dificilmente nele encontrem este último atributo.

Vários monarcas europeus adotaram a pose de Rigaud em trajes majestáticos de Corte. Augusto II, o Forte, rei da Polônia e príncipe-eleitor da Saxônia, por exemplo, fez-se retratar por Louis de Silvestre em 1718, associando as insígnias monárquicas à armadura ${ }^{14}$.

0 padrão de pose em traje real de estado foi seguido também pela própria descendência de Luís XIV, com algumas adaptações. Em 1747, Luís de França, filho de Luís XV, foi retratado por Natoire em trajes de Delfin, na pose exata de Rigaud, embora portasse apenas um bastão de comando, pois sua condição não permitia empunhar o cetro, exclusivo do monarca. Charles-Phillipe, conde de Artois (futuro Carlos X), foi retratado por Callet, retratista da corte de Luís XVI, seu irmão, em traje da ordem do Espírito Santo, numa pose semelhante à do Delfin ${ }^{15}$.

12 No que Peter Burke viu traços de um estudado equilíbrio entre formalidade e informalidade, pois Rigaud assumiu nesse retrato formal de Estado certa ousadia ao inverter o cetro e assemelhá-lo a um simples bastão de apoio, como no retrato de Carlos I por van Dyck. BURKE, Peter. A fabricação do rei: a construção da imagem pública de Luís XIV. Rio de Janeiro: Jorge Zahar, 1994. Tal inovação e ousadia não foram obstáculo a que o retrato fosse adotado como modelo por seus descendentes até o fim do Antigo Regime. BURKE, Peter. Eyewitnessing: the uses of images as historical evidence. Londres: Reaktion, 2001. p. 28-9.

13 PERREAU, Stéphan. Hyacinthe Rigaud: le peintre des rois. Montpellier: Les Presses du Languedoc, 2004. p. 104.

14 Tela pertencente a Gemäldegalerie Alte Meister, Dresden. Ver reprodução em: SPLENDEURS de la cour de Saxe: Dresde à Versailles. Paris: Réunion des Museés Nationaux, 2006.

15 RMN173067 / MV3791; RMN163199 / MV3974. Disponivel em: <http://www. photo.rmn.fr>. 
Alguns dos retratos majestáticos mais célebres dos três últimos reis Luíses, no entanto, rejeitaram a mão esquerda flexionada e apoiada na cintura. Luís XV, por L.M.Van Loo, Luís XVI, por Callet, e Luís XVIII, por Robert Lefèvre, foram retratados com um chapéu na mão esquerda, enquanto Guérin retratou este último com a mesma espalmada ${ }^{16}$.

0 retrato de João VI, feito em 1817 por Debret (Fig. 3), pode ser compreendido como parte da linhagem de representação real derivada dos retratos de Luís XIV, ao que pode ter servido de estímulo o fato deste monarca português ser neto de Dona Mariana de Borbón, infanta de Espanha, e por ela tetraneto do Rei Sol. Debret mantém rigidamente a composição de Rigaud, evitando as inovações na pose inseridas desde o reinado Luís XV, no que se pode entrever uma reação fortemente absolutista solicitada pelo próprio rei Bragança em tempos de intensa oscilação política.

Não é de estranhar-se, portanto, que Debret tenha mantido este cânone do Antigo Regime, embora fosse um pintor do círculo de David (além de seu primo) e, portanto, participante da escola neoclássica que se opunha às soluções de retratística vindas do regime anterior. No Rio de Janeiro, como aponta Elaine Dias, o cânone de Rigaud foi destituído apenas com a emergência da ruptura política da Independência e a constituição do regime imperial brasileiro, que de algum modo evocava seu semelhante francês bonapartista por meio dos retratos inspirados na escola de David. A própria oposição entre as poses de João VI e Pedro I, mantidos lado a lado no terceiro volume da Viagem pitoresca e histórica ao Brasil, publicado por Debret em Paris em 1839, indicava a oposição entre o Antigo Regime e a nova monarquia constitucional americana, que estaria, como destacava o próprio Debret, livre dos abusos que caracterizavam a velha corte lisboeta ${ }^{17}$.

A tradição dos retratos bourbônicos, dissociada de uma monarquia imperial e constitucional, caiu portanto em desuso no Brasil já na terceira década do século XIX. Os retratos da monar-

16 Para Luís XV: RMN17430 / MV3753 (por J.M. Fredou, d'après Louis-Michel Van Loo); RMN169314 / MV6634 (por F. Guérin, d'après Louis-Michel Van Loo); Para Luís XVI: RMN163192 / MV3890; Para Luís XVIII: RMN2476 / MV6326; RMN169315 / MV4793. Disponível em: <http://www.photo.rmn.fr>. 0 retrato de Luís XVI realizado por Caillet foi apresentado no Salão de 1789, aberto em agosto, e mantinha com ligeiras alterações o padrão de Rigaud, apesar do período de crise da monarquia absolutista. Ver: ALLARD, Sébastien et al. Portraits publiques, portraits privés, 1770-1830. Paris: Réunion des Musées Nationaux, 2006. p. 68-9.

17 DIAS, Elaine. A representação da realeza no Brasil: uma análise dos retratos de D. João VI e D. Pedro I, de Jean-Baptiste Debret. Anais do Museu Paulista História e Cultura Material, São Paulo, v. 14, n. 1, p. 247-9, 258, jan.-jun. 2006. 
quia bragantina ou das elites imperiais espelharam-se nos novos modelos gerados pelas cortes da Europa Ocidental, sobretudo de Luís Felipe d'Orléans e Napoleão III, em que o intimismo, as vestes discretas e as poses de gestual contido alteraram radicalmente o padrão de representação do Antigo Regime.

Quando, em 1903, Benedito Calixto realizou o já mencionado quadro Domingos Jorge Velho e o loco-tenente Antônio Fernandes de Abreu, o cânone baseado em Rigaud reapareceu. Ao longo das décadas de 1910 e 1920, foi replicado em outras obras encomendadas pelo Museu Paulista.

Tal emergência relacionava-se certamente com uma visão triunfalista e heroicizante atribuída aos bandeirantes - e à própria história paulista - por historiadores paulistas ligados ao Instituto Histórico e Geográfico de São Paulo, fundado em 1894. Diversos estudos já apontaram a decisiva atuação desses historiadores, como Affonso Taunay e Washington Luís, na publicação ou no estímulo à produção dos primeiros trabalhos que almejavam constituir um eixo de interpretação da história do Brasil que passasse decisivamente pela história paulista. Esta concepção opunha-se à corrente historiográfica consolidada pelo Instituto Histórico e Geográfico Brasileiro, inspirada nas obras pioneiras de Martius e Varnhagen, que compreendia a história do Brasil como nação a partir da experiência da implantação da corte no Rio de Janeiro e da consolidação do estado monárquico centralizado durante o Segundo Reinado ${ }^{18}$.

0 Museu Paulista, durante as gestões de Hermann Von Ihering de Affonso d'Escragnole Taunay, foi recebedor de numerosas obras de arte que representavam - e que materializavam aos olhos do público - as seqüências de eventos ou de personagens históricos que definiam teleologicamente a trajetória brasileira a partir do protagonismo paulista. Nesse âmbito, as figurações de bandeirantes segundo a pose de Rigaud formaram um grupo especialmente relevante.

18 Quanto à constituição de uma vertente paulista na compreensão da trajetória histórica do país, o que inclui o destaque aos bandeirantes sobretudo nas publicações editadas a partir da década de 1910, ver: ABUD, Kátia Maria. $O$ sangue intimorato e as nobilíssimas tradições: a construção de um símbolo paulista, o bandeirante. 342 f. 1986. Tese (Doutorado) - Faculdade de Filosofia, Letras e Ciências Humanas, Universidade de São Paulo, São Paulo, 1986. esp. cap. 3. FERREIRA, Antônio Celso. A epopéia bandeirante: letrados, instituições, invenção histórica (1870-1940). São Paulo: Editora Unesp. 2002. cap. 2. SCHWARCZ, Lilia K. M. Os guardiões da nossa história oficial. São Paulo: Idesp, 1989. p.45-56. Quanto à ambição dos historiadores do IHGSP em exaltar a primazia paulista na história brasileira vale lembrar ainda uma vez as célebres palavras encontradas no primeiro volume da revista deste instituto: "A história de São Paulo é a própria história do Brasil". 


\section{0 retrato de "uma glória paulista": entre investigação histórica e convenção pictórica}

Embora a gestão Ihering (1895-1916) seja associada imediatamente à configuração do Museu Paulista como um museu de História Natural - o que o colocava em contraponto ao Museu Nacional e ao Museu Paraense - foi ainda nela que o museu passou a fazer as primeiras grandes aquisições de telas de temática histórica ligada ao passado paulista, para além da tela pioneira de Pedro Américo, Independência ou Morte ${ }^{19}$. Durante os cinco primeiros anos da instituição, esta obra permaneceu como o único exemplo de pintura histórica do acervo, até que, para as comemorações do $4^{\circ}$ Centenário do Descobrimento do Brasil, adquiriu-se nova obra de arte do gênero histórico, capaz de expressar uma visão oficial do evento.

Ainda em 1900, ocorreu a aquisição, mediante doação, da tela de grande formato Fundação de São Vicente, de Benedito Calixto $^{20}$, numa celebração antecipada do início do povoamento vicentino. Associava-se, deste modo, o grande evento do passado nacional ao que se considerava ser seu decisivo desdobramento "paulista", o início efetivo da colonização, ocorrido apenas em 1532. Assim, o eixo de comemoração do Centenário do Descobrimento deslocava-se do litoral baiano para o paulista, ainda que isto implicasse um malabarismo temporal.

Dois anos após o festejo da efeméride, o Museu Paulista recebeu a tela Desembarque de Pedro Álvares Cabral em Porto Seguro em 1500. A chegada dos portugueses às costas do que viria a ser a Bahia era, assim, finalmente aludida no mesmo museu em que já se celebrava a fundação da primeira vila em terras posteriormente consideradas paulistas $^{21}$. No ano anterior, em 1901, outra pintura

19 Quanto à entrada de pinturas e acervos de objetos ligados à temática histórica na gestão Ihering, ver: MORAES, Fábio Rodrigo de. Uma coleção de história em um museu de ciências naturais: o Museu Paulista de Hermann Von Ihering. Relatório (Iniciação científica - Fapesp) - Museu Paulista, Universidade de São Paulo, São Paulo, 2006. Exemplar disponível na biblioteca do Museu Paulista da USP, São Paulo.

20 Carta de Hermann von Ihering à Secretaria de Interior, 12 nov. 1900. Apud: MORAES, Fábio Rodrigo de. Uma coleção de história em um museu de ciências naturais: o Museu Paulista de Hermann Von Ihering. Relatório (Iniciação científica - Fapesp) - Museu Paulista, Universidade de São Paulo, São Paulo, 2006. anexo, p. 19. Sobre a aquisição desta obra ver também: ALVES, Caleb Faria. Benedito Calixto e a construção do imaginário republicano. Bauru: Edusc, 2003. p. 213-26.

21 Carta da Secretaria de Interior a Hermann von Ihering, 27 de agosto de 1902. Carta de Hermann Von Ihering à Secretaria de Interior, 28 de agosto de 1902. Apud: MORAES, Fábio Rodrigo de. Uma coleção de história em um museu de ciências naturais: o Museu Paulista de Hermann Von Ihering. Relatório (Iniciação científica - Fapesp) - Museu Paulista, Universidade de São Paulo, São Paulo, 2006. anexo, p. 29. 
histórica, Partida da monção, concluída por Almeida Júnior em 1897, fora incorporada ao acervo mediante compra ${ }^{22}$. Constituíase assim um conjunto de telas de grande formato que estabelecia o primeiro nexo linear entre o descobrimento e a independência, mediado necessariamente por eventos associados aos paulistas.

A tela Independência ou Morte constituiu, portanto, uma célula inicial das evocações do passado simultaneamente paulista e brasileiro - simbiose que seria multiplicada já desde 1900 mediante a aquisição de pinturas de formato similar, capazes de conferir a condição de lugar de memória ao museu e veracidade aos eventos por elas referidos.

Também a partir de 1902, o Museu Paulista passou a receber os dois primeiros exemplares de uma série de pinturas de formato menor encomendadas por Ihering a Benedito Calixto, os quais representavam o padre Anchieta e o imperador Pedro I ${ }^{23}$. Estas telas continham retratos de próceres da história a um só tempo brasileira e paulista, expandindo a evocação do passado pensado de maneira inseparavelmente binária pela historiografia local. Os retratos de Anchieta e Pedro I foram realizados a óleo, numa composição que privilegiava a representação dos corpos entre as coxas e a cabeça, recorte característico da pintura oitocentista, incorporado pela cultura fotográfica da segunda metade do século XIX.

A pose utilizada procura lembrar, no caso de Pedro I, os retratos da primeira metade do século XIX característicos das elites imperiais, com roupas civis e condecorações. D. Pedro I é representado em pé, apoiado ligeiramente na balaustrada de um fictício belvedere no Brás, com a várzea do Carmo e a face leste do centro paulistano em segundo plano. Sua pose em nada remete aos cânones da retratística monárquica dos Bourbon ou Bonaparte, nem aos retratos de Corte realizados no Rio de Janeiro para os Bragança. José de Anchieta foi representado já idoso e em pé, vestindo o hábito jesuítico e apoiado numa haste, sendo figurado numa praia - alusão provável a sua permanência em Ubatuba. Esta tela constitui, aliás, uma das únicas referências aos jesuitas no acervo

22 Carta de Hermann von Ihering à Secretaria de Interior, 03 de outubro de 1901 apud MORAES, Fábio Rodrigo de. Uma coleção de história em um museu de ciências naturais: o Museu Paulista de Hermann Von Ihering. Relatório (Iniciação científica - Fapesp) - Museu Paulista, Universidade de São Paulo, São Paulo, 2006. p. 21. A obra foi adquirida em 26 de agosto de 1901. Cf. MUSEU PAULISTA. SVDHICO. Diário Popular, 27 ago. 1901.

23 Carta de Benedito Calixto a Hermann von Ihering, 01 de fevereiro de 1902; carta de Hermann von Ihering à Secretaria de Interior, 26 de fevereiro de 1902 apud MORAES, Fábio Rodrigo de. Uma coleção de história em um museu de ciências naturais: o Museu Paulista de Hermann Von Ihering. Relatório (Iniciação científica - Fapesp) - Museu Paulista, Universidade de São Paulo, São Paulo, 2006. anexo, p.25. 
de obras de arte do Museu Paulista. 0 que se explica pelo fato de, durante décadas, a figuração e exaltação dos povoadores e bandeirantes ter sido largamente preferida pelos diretores da instituição, em detrimento da ação catequética dos padres da Companhia.

Baseados em imagens antigas que continham traços fisionômicos e indumentária dos homenageados, conforme o próprio Calixto informou ${ }^{24}$, estes dois primeiros retratos ganhavam veracidade devido a esta filiação documental, que diluía as fronteiras entre sua realização contemporânea e a evocação de personagens havia muito falecidos, que jamais poderiam ter posado para Calixto. Os retratos poderiam, portanto, ser expostos no Museu Paulista como parte da coleção de pinturas históricas sem que as ambições positivistas dos historiadores do IHGSP fossem comprometidas.

No ano seguinte, em 1903, o museu recebeu mais dois retratos do mesmo pintor, dedicados a Vicente da Costa Taques Góes e Aranha, capitão-mor de Itu, e aos bandeirantes Domingos Jorge Velho e Antônio Fernandes de Abreu, ambos participantes da destruição do quilombo de Palmares, ao longo da década de $1690^{25}$.

0 retrato do líder ituano, célebre pela refrega com o príncipe-regente, que tentou ridicularizá-lo em 1822, apresenta-o em traje formal de acordo com a aquarela de Miguel Arcanjo da Assunção, o Miguelzinho Dutra, realizada por volta da década de 1840. Esta aquarela, hoje pertencente ao acervo do Museu Republicano Convenção de Itu, foi muito provavelmente a mesma examinada por Calixto, conforme o mesmo declara em carta de 1919, em que descreve sua tela como "cópia fiel” da aquarela "obtida pelo Dr. Antonio Piza"26. Seu informante foi certamente Antonio de Toledo Piza e Almeida, historiador, membro fundador e primeiro secretário do IHGSP e diretor do Arquivo do Estado, falecido em 1905.

24 "O retrato de D. Pedro I foi fielmente reproduzido (o busto) de miniatura que existe em poder do Cap. Leite (...), a qual lhe mostrei. 0 de Anchieta é igualmente cópia de um retrato antigo, o qual antes de reproduzir mostrei e consultei ao sr. Teodoro Sampaio que concordou ser o mais autêntico". Cf. carta de Benedito Calixto mencionada na nota anterior.

25 Carta da Secretaria de Interior a Hermann Von Ihering, 03 de março de 1903 apud MORAES, Fábio Rodrigo de. Uma coleção de história em um museu de ciências naturais: o Museu Paulista de Hermann Von Ihering. Relatório (Iniciação científica - Fapesp) - Museu Paulista, Universidade de São Paulo, São Paulo, 2006. anexo, p.33. O Museu Paulista ainda recebeu mais dois quadros de Calixto, dedicados a José Bonifácio e Bartolomeu de Gusmão, em 1911. Ibidem, p. 62

26 Carta de Benedito Calixto a Affonso Taunay, 09 de abril de 1919. MUSEU PAULISTA. SVDHICO. A mesma referência à "cópia fiel de uma miniatura da época” está também mencionada em notícia do Diário Popular, p.1, 27 fev. 1903. Acervo do Arquivo do Estado de São Paulo, São Paulo. Há uma reprodução da aquarela de Migulezinho Dutra em: BARDI, Pietro Maria. Miguel Dutra: o poliédrico artista paulista. São Paulo: MASP, 1981. p. 95. 
0 outro retrato, denominado Domingos Jorge Velho e o loco-tenente Antônio Fernandes de Abreu (Fig. 4), é especialmente importante para a história do Museu Paulista e para a própria trajetória da pintura histórica paulista, pois foi, ao que se pôde levantar até o momento, a primeira obra de arte dedicada à representação de bandeirantes realizada em São Paulo no período republicano e também a primeira obra com este tema a ser incorporada ao acervo do Museu Paulista. Ela inaugura uma longa trajetória de produção de imagens, bidimensionais e tridimensionais, que procuravam celebrar os antigos sertanistas mediante representações imponentes, capazes de comunicar nos espaços públicos ou em museus o caráter heróico que começava a ser atribuído aos bandeirantes pelos historiadores paulistas.

A obra de Calixto opõe-se, nesse sentido, a uma tela anterior de Henrique Bernardelli denominada Os bandeirantes, concluída na Itália em 1889, hoje pertencente ao Museu Nacional de Belas Artes do Rio de Janeiro. Neste quadro, dois bandeirantes foram representados em primeiro plano bebendo água, atirados ao chão e observados por índios aprisionados, que permanecem sentados ou em pé. Figurados como animais saciando a sede, os bandeirantes não têm nessa pintura qualquer sentido de heroísmo, como aponta Maraliz Christo ${ }^{27}$.

A tela dedicada ao destruidor de Palmares e seu lugar-tenente é por certo bem anterior à vaga de publicações que exaltavam as bandeiras paulistas, surgida sobretudo após a década de 1910, e que terá entre seus expoentes os trabalhos de Affonso Taunay ou Alfredo Ellis. Entretanto, pode-se compreendê-la ligada à fase embrionária deste movimento, em que a celebração ainda se expressava em obras genealógicas e romances.

Desde a década de 1890, vinham sendo publicadas genealogias de famílias paulistas das elites cafeeiras que procuravam vincular-se ao passado vicentino e bandeirante ${ }^{28}$. A publicação dos manuscritos de Pedro Taques, a célebre Nobiliarquia paulistana, empreendida pelo IHGB a partir de 1869, foi certamente o estímulo inicial para a recuperação histórica dos feitos sertanistas, capazes de configurar dignidade ao economicamente

27 CHRIST0, Maraliz de Castro Vieira. Bandeirantes ao chão. Estudos Históricos, Rio de Janeiro, n. 30, p. 33-55, 2002.

28 Veja-se por exemplo as obras: BONILHA, Manuel Martins. Genealogia dos Martins Bonilha, Toledo Piza e Amaral Gurgel, do estado de São Paulo, Brazil. Rio de Janeiro: 0 Tempo, 1893; CASTRO, Luís Porto Moretzsohn de. Apontamentos genealógicos: famílias paulistas e européias com que se entrelaçam os Paes de Barros, Penteados de Ytú e Vasconcellos Vergueiros de S. Paulo. Santos: [s.n.], 1900. 
modesto passado paulista. Antônio de Toledo Piza, já em 1895, escrevera como secretário do IHGSP ao IHGB solicitando permissão para a reedição da obra de Pedro Taques ${ }^{29}$. A Genealogia paulistana, publicada por Luís Gonzaga da Silva Leme entre 1903 e 1905, é a expressão máxima desta recuperação genealógica ocorrida nas primeiras décadas da República em São Paulo, e que se alicerçava em investigações nos velhos inventários, testamentos e registros eclesiásticos do período colonial.

No tocante especificamente à exaltação de Domingos Jorge Velho e da campanha contra os quilombolas da Serra da Barriga, pode-se ainda recuar até 1885 , quando Joaquim de Paula Souza publicara o romance Os Palmares. Longe de empalidecer a vitória do sertanista paulista, como sugeria a obra de Rocha Pitta, Paula Souza almejava "chamar attenção sobre aquella importante guerra, e tornar conhecidos os paulistas e seus auxiliares, tão dignos de sumpathia", descrevendo "aquele tempo em que havião tantos heroísmos, em que o paulista era o typo de homem de bem". Como fontes, o literato consultara novamente os "testamentos e velhos papeis que nos deixarão os antigos”, além dos relatos de Souza Botelho (1775), do marquês de Lavradio (1775) e de Saint-Hilaire, do qual lembrara textualmente a expressão "raça de gigantes" 30 .

A composição do retrato de Domingos Jorge Velho e Antônio Fernandes de Abreu, realizado por suposição, fundamentouse tanto na investigação de informações com base documental textual e em memórias orais, quanto em convenções pictóricas. Nesta terceira vertente, será constatada a referência à pose estabelecida nos retratos monárquicos de tradição francesa, consolidada por Hyacinthe Rigaud.

Benedito Calixto compôs a tela em quatro planos. Situou Domingos Jorge Velho em primeiro plano, Antônio Fernandes de Abreu, seu lugar-tenente quando do breve retorno a São Paulo, em segundo, árvores em terceiro e uma serra em quarto. 0 ambiente é, portanto, externo ao espaço urbano. Não há referência explícita ao episódio de Palmares, pois a tela é rigorosamente um retrato e não uma narrativa ou um episódio tal como ocorria nas telas de grande formato já existentes no acervo do Museu Paulista.

29 Cf. TAUNAY, Affonso d'E. 0 historiador dos bandeirantes - Pedro Taques e sua obra. In: LEME, Pedro Taques de Almeida Paes Leme. Nobiliarquia paulistana histórica e genealógica. Belo Horizonte: Itatiaia; São Paulo: Edusp, 1980. p.43-44.

30 SOUZA, Joaquim de Paula. Os Palmares: romance nacional histórico. Rio de Janeiro: Laemmert, 1885. p. 13, 8, 14, 19. 0 exemplar consultado encontra-se na Seção de Livros Raros da Biblioteca Municipal Mário de Andrade, São Paulo. 
Se para os dois primeiros retratos encomendados a Benedito Calixto havia informações visuais sobre a aparência dos retratados, assim como sobre o capitão mor de Itu, para a tela dos bandeirantes não havia iconografia de suporte. De fato, ao que se sabe até o momento, não restou nenhuma representação visual de sertanistas paulistas realizada no período colonial. 0 retrato alusivo a Domingos Jorge Velho e Antônio Fernandes de Abreu é, assim, bastante singular na série em que se insere pois, para sua realização, Calixto recorreu às fontes textuais e orais, não às visuais. Nesse sentido, a tela situa-se num delicado equilíbrio entre a sustentação em documentos considerados autênticos, assegurando o vínculo com a realidade do que se acreditava ter ocorrido no passado, vínculo ambicionado pelos historiadores do IHGSP, e a imaginação e idealização baseadas em convenções pictóricas.

Toledo Piza não dispunha, para subsidiar o retrato dos bandeirantes, de uma aquarela como aquela de Miguelzinho Dutra, que indicara a Calixto para a realização do retrato de Vicente da Costa Taques Góes e Aranha. No entanto, Piza permaneceu como interlocutor decisivo do pintor para que o trabalho chegasse a um resultado considerado pertinente, já que intermediou uma correspondência entre Calixto e historiadores de seu círculo, capazes de opinar sobre como compor o retrato de personagens históricos sem referências de documentação visual. Toledo Piza publicou na edição do Correio Paulistano de 28 de fevereiro de 1903, no mesmo mês da exposição pública do retrato dos bandeirantes na Casa Aguiar, em São Paulo, um artigo em que transcrevia as respostas de Teodoro Sampaio e de Washington Luís às indagações de Calixto sobre como representar as vestes de Domingos Jorge Velho e seu lugar-tenente. As opções oscilavam entre representar o bandeirante "como militar e mestre de campo que era ou se como sertanejo".

A dúvida residia na possibilidade de retratar Domingos Jorge Velho em fardamento de mestre-de-campo, como oficial de armas português, ou se na vestimenta que se consolidaria como a típica dos bandeirantes: chapéu de abas largas, camisa e calças de algodão, manto e botas de cano alto. Tais itens de indumentária aparecem nas descrições existentes em inventários ou nos legados de testamento, compulsados por historiadores e genealogistas desde as últimas décadas do século XIX, mas pode-se supor que parte deles fosse mais presente nos espaços urbanos e cerimônias do que resistentes, ou suportáveis, às longas, extenuantes e quentíssimas marchas pelos sertões.

Benedito Calixto submeteu sua intenção inicial de representá-lo em uniforme português a Teodoro Sampaio e a Washington Luís. 0 primeiro aquiesceu e o segundo a rejeitou. As palavras dos dois historiadores sintetizam e reapresentam o duelo 
entre idealistas e realistas, travado ao longo da segunda metade do século XIX na crítica da pintura acadêmica européia e brasileira $^{31}$. Teodoro Sampaio respondeu a indagação optando por qualificar o retratado não sob o rigor das fontes, mas numa imagem construída em correspondência com o grau de dignidade daquele a quem denominava "o vencedor de Palmares" e que integraria uma série de pinturas destinadas a representar "os feitos gloriosos dos filhos de São Paulo". Diz ele em sua resposta a Calixto:

Estou de accôrdo com o esboço do quadro projectado, e com o modo de representar a figura do famoso paulista. Um quadro historico referente a uma data tão remota, da qual poucas informações precisas e minuciosas temos sobre o trajar dos homens, tem de ser, por via de regra, uma cousa convencional e approximada, reproduzindo um pouco do que se sabe ao certo e um pouco dos costumes da época que mais se lhe aproxime. Ora, não é de crer que Domingos Jorge Velho se apresentasse a batalhar com os seus mamelucos caracterizado como um mestre de campo. De certo, a parte decorativa equivalente ao seu posto militar não foi exibida na acção. Nós temos exemplo disso, bem perto de nós, na guerra do Paraguai e na última revolução do Rio Grande: nenhum general se apresentava em campo com a sua farda; timbravam quase sempri em se apresentar a gaúcha. Num quadro histórico, porém, não há só a considerar a verdade ou realidade do facto; há também a parte propriamente artística ou de effeito esthético, há a licção de cousas. Caracterizando o vulto de Domingos Jorge como trajava qualquer sertanejo mais abastado ou a bandeirante, não se conseguirá do quadro a demonstração ou a idéa que se tem em vista alcançar. É mister, portanto, sacrificar um tanto a realidade á ficção, no intuito de se conseguir maior força de expressão. Acho, pois, acertada a sua resolução de caracterizar o famoso vencedor dos Palmares pelo modo pelo qual m'o descreveu. ${ }^{32}$

Suas palavras indicam claramente a adesão a uma concepção idealista a orientar o quadro. 0 caráter moral do retrato deveria sobrepor-se a uma veracidade radical na representação do antigo paulista. A indumentária portuguesa seria a mais adequada embora improvável, opção ideal que se justificava de maneira

31 MATTOS, Claúdia Valladão de. Imagem e palavra. In: OLIVEIRA, Cecília Helena de Salles; MATTOS, Claúdia Valladão de (Org.). 0 brado do Ipiranga. São Paulo: Edusp; Museu Paulista, 1999. p. 119-32.

32 CORREIO PAULISTANO. São Paulo, p. 1, 28 fev. 1903. (nº 14.199). Acervo do Arquivo do Estado de São Paulo, São Paulo. (Grifos nossos). 
a reforçar a hierarquia, a grandeza do feito e o reconhecimento régio. Perpetuar-se-ia assim sua mensagem moral, garantindo-se o caráter pedagógico - a lição das coisas.

Washington Luís, então um político e historiador iniciante, pretendia uma interpretação balizada pela realidade, informada por fontes que considerava verídicas. Aliava a crença radical na veracidade dos relatos orais sobre a aparência física dos sertanistas a conjecturas quanto à sua indumentária, guiadas pela crença no caráter prático demandado pelas longas caminhadas. Ao referir-se ao primeiro aspecto, evitava qualquer dúvida prudente, estribando-se na descrição encontrada no mencionado romance Os Palmares, de Joaquim de Paula Souza ${ }^{33}$. Segundo Washington Luís, nesta obra, o autor "cingiu[-se] estritamente à verdade nas suas descrições”, pois, além de consultar a documentação textual, o que era expresso pelo próprio Paula Souza, alicerçara-se na memória oral repassada por gerações de ituanos, "que tinham razão de saber porque repetiam o que tinham ouvido de seus maiores, numa tradição constante e uniforme”. Benedito Calixto optou por seguir rigorosamente as indicações dessa carta, pois sua pintura acompanhou de perto a descrição de Domingos Jorge Velho constante no romance de Paula Souza, transcrita por Washington Luís:

Era alto, robbusto, de uma apparencia imponente; tinha os cabelos ruivos, cortados rente, os olhos azues, o rosto comprido, alvo, corado na pequena parte que não era coberta pelo espesso bigode, e comprida barba ruiva que lhe descia ao peito. ${ }^{34}$

Antonio Fernandes Abreu, seu lugar-tenente, seria, segundo Paula Souza:

[...] meão de altura, pescoço curto e grosso, hombros largos, corpo reforçado; a cabeça era bem feita, a testa um tanto saliente, os olhos pequenos e vivos, os bigodes aparados. No cuidado com que se vestia e tratava e nas suas mesmas acções, via-se que caprichava em mostrar um soldado escravo da disciplina. ${ }^{35}$

33 Washington Luís transcreveu as descrições de Jorge Velho e de Antônio Fernandes de Abreu localizadas respectivamente às páginas 140 e 183 da obra Os Palmares.

34 CORREIO PAULISTANO. São Paulo, p. 2, 28 fev. 1903. Calixto também seguiu a indicação etária designadas pelo próprio W. Luís: "nessa época, era um homem de 70 anos de idade, mais ou menos".

35 CORREIO PAULISTANO. São Paulo, p. 2, 28 fev. 1903. 
No que concerne à indumentária a ser representada na tela, Washington Luís sustentava o caráter conjetural da solução a ser definida, embora indicasse a necessidade de respeitar a rusticidade das lides nos sertões como base para a sua suposição. Ressalvava que

Hoje parece-me muito difícil, sinão impossivel, determinar com exactidão se Domingos Jorge, na occasião da tomada dos Palmares, vestia a farda de mestre de campo das tropas regulares portuguezas ou se trajava o vestuário clássico do sertanista de S. Paulo, conquistador dos índios e devassador do sertão. Neste particular só podemos caminhar por conjeturas. Que Domingos Jorge Velho era mestre de campo não há que duvidar, mas que ele o era de um terço de paulistas é também fora de dúvida. E quem diz "terço de paulistas" entende tropas não regulares, no sentido de não estarem a soldo da metrópole portugueza, o que é confirmado pelo contrato feito entre Domingos Jorge e o representante da metropole para a destruição dos Palmares, quando, para tal fim, se ele fosse militar assoldado, commandando soldados pagos, bastaria uma simples ordem superior. Ele poderia, pois, estar fardado ou trazer o costume habitual do sertanista, dependendo isso de suas posses, de sua educação, de seu temperamento, de seu modo pessoal de ver as cousas, de sua tendência para a ostentação ou para a simplicidade, da impressão que quizesse produzir nos seus e nos alheios soldados, caso nisso pensasse. ${ }^{36}$

Após referir-se ao rigor das lutas, à subsistência improvisada quotidianamente nas matas e à parca herança recebida, concluiu que

Por temperamento, pelos habitos e educação, pelas próprias condições dessa guerra singular, Domingos Jorge não poderia estar vestido de sedas e velludos; não se distinguiria pelo fausto do vestuario, mas pela bravura, energia, tenacidade, resistencia ao soffrimento, desprezo ao perigo.

Elle deveria estar, sem duvida, com o vestuário clássico do sertanista, do bandeirante, que, em resumo, é o typo glorioso de S. Paulo. ${ }^{37}$

Washington Luís seguira Paula Souza no tocante à compreensão do traje dos paulistas como distinto dos portugueses. Para

36 CORREIO PAULISTANO. São Paulo, p. 1, 28 fev. 1903.

37 Ibid. p. 1, 28 fev. 1903. 
este escritor, em trecho não transcrito pelo historiador, os sertanistas eram necessariamente diferentes dos militares portugueses:

Os heróes do Brazil não se trajão como os portuguezes, com riqueza e luxo, com soberbo capacete, e o elegante morrião cahindo-lhe ap lado, não tem o nobre aspecto dos barões de além mar. Vestem-se com a maior singeleza; mas, em que peze aos euopeus não lhe são inferiores. ${ }^{38}$

A opção pela roupa rústica dos sertões atendia ainda a uma despudorada ambição de representar Domingos Jorge Velho como um exemplo para os paulistas do período republicano:

Fardado de mestre de campo das milícias portuguezas, não obstante ter nascido na Capitania de S. Paulo, Domingos Jorge Velho seria uma glória portugueza; vestido como vestiam os sertanejos, elle, embora colono de Portugal, é uma glória paulista. ${ }^{39}$

As considerações de Washington Luís evidenciavam a importância que a experiência bandeirante teria para o círculo de historiadores do IHGSP nas décadas seguintes. A evocação dos sertanistas como heróis tornava-se a peça chave da constituição de um ethos paulista, cujo extravasamento chegaria ao próprio Brasil. Justificava-se, nas palavras do então jovem historiador, que essas "expedições, que tanta gloria deixaram a S. Paulo e que de tanto valor foram para a constituição geográphica do paiz" fossem homenageadas em tela. Sendo assim, o próprio Calixto plasmar-se-ia no sentido de sua obra pictórica, pois "a perpetuação de uma glória paulista [seria] para vossa senhoria também uma glória”.

Calixto além de pintor era também historiador. Realizar um retrato suposto constituía um desafio, tendo em vista a necessidade de conferir veracidade histórica, capaz de assegurar sua dignidade e eficiência ao entrar para a galeria de pinturas históricas do Museu Paulista. Para tanto, a consulta a documentos textuais poderia informar ao menos sobre a indumentária adequada ao personagem. A opção pelo traje paulista sugerido por Washington Luís foi, contudo, duramente contestada no mesmo Correio Paulistano em artigo assinado por Alberto Souza, logo após a publicação do texto de Toledo Piza. Souza lembrava em seu artigo que a proposta inicial do quadro previa uma cena de batalha em grande formato, em que Jorge Velho comandava tropas paulistas e portuguesas, o que fora

38 SOUZA, Joaquim de Paula. Os Palmares: romance nacional histórico. Rio de Janeiro: Laemmert, 1885. p. 8.

39 CORREIO PAULISTANO. São Paulo, p. 2, 28 fev. 1903. 
inviabilizado pelo pequeno orçamento destinado pelo legislativo à encomenda da pintura. Não obstante soubesse que o formato final reduzira-se ao de um retrato, advertia que:

[...] Seria de um effeito summamente desastrado, portanto, que na grandiosa composição dum quadro de batalha, ao lado das plumas coloridas, ondulando no espaço no tope dos capacetes, e por entre alamares doirados e as dragonas faiscando ao sol dos dias do equador, se destacasse ridiculamente o personagem principal desse episodio guerreiro com seu enorme chapelão de coiro a tres pancadas e a sua japona de baeta azul retrancada sobre os hombros... ${ }^{40}$

Alberto Souza optara pela idealização preconizada por Teodoro Sampaio, com quem se alinhava abertamente em sua crítica, embora terminasse por concordar com a opção de Calixto, já que a tela reduzira-se a um retrato imaginado. No entanto, refutava o rigor da opção "realista", científica, a seu ver inapta à representação de um vulto. Para ele, que aderia claramente aos princípios idealistas, "na pintura histórica tem sempre o artista a liberdade de concepção e de execução mais ampla do que geralmente se supõe", e

[...] muito embora estivesse historialmente demonstrado que o bandeirante se apresentara em campo com a tradicional japona patrícia, a garrucha a tiracolo e outros apetrechos communs ao sertanejo paulista daquellas eras passadas - a verdade é que o pintor para obter a maior soma de effeito artístico e para revestir de maior e mais soberana imponência o typo do famoso heroe, tinha não só o direito, como até o dever e fugir à imposição grosseira da realidade e imaginal-o de grande uniforme, ostentando garbosamente sua farda de soldado portuguez. ${ }^{41}$

Um retrato, suposto que fosse, deveria atender também a um dos princípios do decorum, isto é, a representação adequada à dignidade do personagem ou ao evento cuja mensagem se queria perpetuar na pintura, que devia seguir modelos de composição oficializados pelas academias ${ }^{42}$. Para tanto, o embasamento em fontes justapunha-se também às convenções utilizadas nas representações

40 CORREIO PAULISTANO. São Paulo, n. 14209, p. 1, 10 mar. 1903. Acervo do Arquivo do Estado de São Paulo, São Paulo.

41 CORREIO PAULISTANO. São Paulo, n. 14209, p. 1, 10 mar. 1903.

42 MATTOS, Claúdia Valladão de. Imagem e palavra. In: OLIVEIRA, Cecília Helena de Salles; MATTOS, Claúdia Valladão de (Org.). O brado do Ipiranga. São Paulo: Edusp; Museu Paulista, 1999. p. 125-6. 
da pintura histórica, que aqui deveriam garantir ao menos "a maior e mais soberana imponência ao typo do famoso heroe”. Nesse sentido, Calixto, Teodoro Sampaio, Washington Luís e Alberto Souza aproximavam-se. A mensagem moral deveria ser garantida ${ }^{43}$.

A já mencionada tela Independência ou Morte é exemplar, senão paradigmática, no que se refere à convergência dos fatores compositivos apontados acima. Claúdia Valladão de Mattos, em estudo recente, destacou a necessidade de evitar as noções de erro ou fraude na interpretação da obra de Pedro Américo, na medida em que sua composição atendia simultaneamente à idealização calcada em esquemas acadêmicos e ao embasamento documental, ajustando as proporções dos mesmos numa solução final que conferisse não apenas dignidade, mas também veracidade, realidade ao fato representado. A consciência desta calibragem está, aliás, expressa no próprio texto deixado por Pedro Américo sobre a tela, em que adverte: "A realidade inspira e não escraviza o pintor." ${ }^{4}$

A tela Domingos Jorge Velho e o loco-tenente Antônio Fernandes de Abreu foi concebida tendo em vista a glorificação dos sertanistas paulistas a partir de um exemplo então considerado maior, o "vencedor de Palmares". Sua introdução no Museu Paulista deveria instituir o reconhecimento público de uma imagem que correspondesse ao heroísmo apontado pelos historiadores. Para tanto, além do rigor na escolha da indumentária a ser representada, cabia utilizar uma pose corporal que significasse a magnitude não apenas do retratado, mas de sua própria tipificação bandeirante, eivada de "soberana imponência".

Calixto explicitou a hierarquia entre os dois sertanistas a partir de sua posição nos planos. Acentuando esta distinção, as poses

430 próprio Toledo Piza foi sensível à saída conciliatória de Calixto, que transitava entre o apego de Teodoro Sampaio ao princípio de Horácio - ut picturas poesis - em que a tela deveria ser exemplus virtutis, e o realismo de W. Luís: "Como vêem os leitores, em fundo estão de pleno accordo ambos os distinctos cultores da história nacional, entendendo o dr. Theodoro Sampaio que, na forma, é lícito ao pintor, como ao poeta, sacrificar um pouco a realidade à ficção, para mais impressionar o público pelo effeito esthetico do quadro. Benedito Calixto, entretanto, cingiu-se o mais possível à realidade histórica na pintura do seu quadro, e hoje podemos nos orgulhar vendo reproduzidos o vulto imponente do grande sertanejo paulista e o de seu immediato em commando em uma tela, digna de figurar na galeria do Museu do Ypiranga, para o qual fora encomendado pelo governo." CORREIO PAULISTANO. São Paulo, p. 2, 28 fev. 1903.

44 MATTOS, Claúdia Valladão de. Imagem e palavra. In: OLIVEIRA, Cecília Helena de Salles; MATTOS, Claúdia Valladão de (Org.). O brado do Ipiranga. São Paulo: Edusp; Museu Paulista, 1999. p. 119-132. AMÉRICO, Pedro. 0 brado do Ipiranga ou a Proclamação da Independência do Brasil. In: OLIVEIRA, Cecília Helena de Salles; MATTOS, Claúdia Valladão de (Org.). O brado do Ipiranga. São Paulo: Edusp; Museu Paulista, 1999. p. 19. 
adotadas para cada um dos retratados são radicalmente opostas. 0 loco-tenente foi representado rígido, com a sugestão dos braços rentes ao corpo e as pernas ligeiramente abertas. Já Domingos Jorge Velho foi representado segundo os cânones dos retratos monárquicos de tradição francesa. A pose clássica de Luís XIV foi referida e reelaborada pelo pintor paulista, sem que tal aspecto fosse questionado, ou mencionado, por nenhum de seus interlocutores.

Talvez atento ao que sugeria Teodoro Sampaio, ao evocar a noção de "convenção" para possibilitar uma adequada "lição das coisas", Calixto recorreu ao padrão de Rigaud ao mesmo tempo em que o reelaborava para adaptá-lo ao seu tempo e às demandas simbólicas dos encomendantes.

A escolha deste padrão deve ligar-se a duas motivações. A referência temporal foi por certo um fator de relevo, na medida em que a pose escolhida era característica dos retratos monárquicos e também de chefes militares de fins do século XVII, período em que ocorrera a campanha de Palmares. Retratar Domingos Jorge Velho nesta pose era, portanto, acentuar o caráter transtemporal da composição, expressão mesmo de sua veracidade, embora realizada em 1903.

A associação à majestade dos retratos monárquicos era, sem dúvida, uma maneira de conferir decoro ao retratado, ligando suas qualidades à dimensão majestática de autoridade e força. Tal associação não foi realizada sem que adaptações importantes fossem introduzidas por Calixto, podendo-se entrever nelas uma conciliação das duas vertentes de retratos reais - em indumentária de Estado e em armadura.

Nos retratos de corte, Luís XIV e João VI portavam o manto de arminho, as meias de seda que revestiam as pernas e as perucas de cerimônia, além de empunharem os cetros reais na mão direita. 0 braço esquerdo permanecia apoiado na cintura, aludindo à outra tradição já mencionada, holandesa e flamenga, de evidenciar a alta condição do retratado.

Benedito Calixto inverteu a posição dos braços, a fim de deixar a mão direita livre para acionar o gatilho. Efetuou algumas outras adaptações altamente significativas, que convergiram para as sugestões de representação fornecidas por Washington Luís, as quais objetivavam fazê-lo figurar como "uma glória paulista". No lugar do cetro, o bandeirante empunha uma arma de fogo de cano longo. Este sinal de militaria expande-se na sua cintura, pois uma pistola e uma faca reforçam sua condição de prontidão para o combate, além da espada que se insinua atrás do corpo. 0 manto de arminho foi substituído por outro de provável baeta, uma lã azul, forrado de tecido vermelho. A alta peruca de Luís XIV transmutou-se na ampla aba do chapéu do sertanista e as meias de seda deram lugar às botas de cano alto. 
Se a masculinidade dos retratos régios de Estado era conferida pela suntuosidade da indumentária e também pela possibilidade de exposição das formas das pernas (algo que era interditado às mulheres de elite no Antigo Regime e que, para os homens, cairia em total desuso, quando não em ridículo, na era burguesa), na tela de Calixto - pertencente já ao século XX - a masculinidade era acentuada pelas armas, pelo disfarce da pose afetada do braço direito sob o manto e pelas barbas volumosas. Um eventual sentido de feminilidade conferido extemporaneamente aos antigos retratos monárquicos era, assim, evitado pelo embrutecimento dos atributos do retratado ${ }^{45}$.

A conciliação entre a força majestática e a figura do sertanista materializou-se mediante a adaptação dos atributos encontrados nos retratos "em armadura". 0 bastão de comando converteu-se em arma de fogo e a couraça metálica na roupa "à bandeirante". Já as botas de cano alto eram semelhantes àquelas encontráveis nesses retratos franceses. 0 cenário, ao ar livre, era também similar ao que se encontrava na grande maioria dos retratos europeus "em armadura".

Conciliava-se assim uma herança pictórica com novos sentidos, capazes de atualizar e novamente validar a convenção dos retratos régios da tradição bourbônica na experiência artística paulista do início do século XX. A solução compositiva de Calixto acabaria por tornar-se, ela própria, uma convenção para a pintura e escultura históricas dos bandeirantes. Seu sucesso, que certamente deriva também do fato de ter sido adquirida pelo Museu Paulista, confirmar-se-ia nas décadas seguintes quando Taunay, o terceiro diretor da instituição, encomendou uma grande quantidade de obras de arte para criar um cenário, um "teatro da memória" para as comemorações do centenário da Independência e do que considerava ser a decisiva atuação dos paulistas na formação do Brasil.

\section{Difundindo um padrão pictórico durante a gestão de Affonso Taunay}

A pose estabelecida na tela Domingos Jorge Velho e o locotenente Antônio Fernandes de Abreu foi diversas vezes retomada em obras encomendadas pelo Museu Paulista entre fins da década de 1910 e meados da seguinte. Todas elas faziam parte do projeto decorativo da caixa central vertical do edifício do Museu Paulista idealizado por Taunay, que apresentava, por meio de obras de arte de gênero histórico, uma linha da história simultaneamente

45 Agradeço a Vânia Carneiro de Carvalho e a Heloisa Barbuy pelas considerações a respeito das mutações nos padrões de representação do gênero masculino entre os séculos XVIII e XIX. 
brasileira e paulista que se estendia do povoamento vicentino à Independência. Por meio dessas obras, fornecia-se uma narrativa visual para o público, que será composta sobretudo de retratos e, em menor escala, de telas narrativas. Uma pintura, Ciclo da caça ao indio, de Henrique Bernardelli, e três esculturas, Manuel Preto, de van Emelen, Manuel de Borba Gato, de Nicola Rollo, e Fernão Dias Paes Leme, de Luigi Brizzolara, apresentam claros vínculos com a tela de Calixto e, indiretamente, com a retratística monárquica francesa do período bourbônico.

0 painel em óleo sobre tela de Henrique Bernardelli denominado Ciclo da caça ao indio (Fig.5) foi encomendado para ornar um segmento das paredes da escadaria. Está localizado ao lado esquerdo da escultura que representa Pedro I, realizada pelo escultor Rodolfo Bernardelli, irmão de Henrique. 0 pintor foi contatado, como outros artistas do Rio de Janeiro, em 1919, para fazer obras de arte destinadas ao programa decorativo a ser inaugurado nas comemorações do Centenário da Independência ${ }^{46}$.

H. Bernardelli utilizou na versão definitiva da tela a pose de Rigaud, retomada por Calixto. Esta solução, entretanto, foi antecedida de outras tentativas, constatadas em documentos existentes na capital paulista que serão abordados a seguir. A tela foi entregue em agosto de 1922, a tempo de poder ser incluída na inauguração da exposição do Centenário ${ }^{47}$.

Maraliz Christo já apontou que este painel foi o segundo realizado por H.Bernardelli, tendo em vista que Taunay implicara de tal maneira com a primeira versão, sobretudo com a figuração de um cachorro, que o pintor optou por realizar nova pintura. Taunay intervinha constantemente nas encomendas, de modo a assegurar o mesmo equilíbrio demonstrado por Calixto, que oscilava entre o decoro e a veracidade histórica ${ }^{48}$.

46 BREFE, Ana Claudia Fonseca. O Museu Paulista: Affonso de Taunay e a memória nacional, 1917-1945. São Paulo: Editora Unesp; Museu Paulista, 2005. p.121.

47 Taunay solicitou o pagamento da obra à Secretaria do Interior em julho de 1922; a obra foi enviada por Bernardelli em agosto. MUSEU PAULISTA. SVDHICO. Carta de Affonso de Taunay ao Secretário do Interior, 28 jul. 1922; MUSEU PAULISTA. SVDHICO. Carta de Henrique Bernardelli a Affonso Taunay, 15 ago. 1922.

48 CHRISTO, Maraliz de Castro Vieira. Bandeirantes na contramão da História: um estudo iconográfico. Projeto História, São Paulo, 24, p. 313-314, jun. 2002. 0 Museu Paulista possui um estudo da figura do bandeirante utilizada para essa segunda versão, na coleção H.Bernardelli. Ver reprodução em: WITTER, José Sebastião (Coord.); BARBUY, Heloísa; LIMA, Solange Ferraz de (Org.). Acervos do Museu Paulista / USP. São Paulo: Imesp, 1999. p.78. Sobre as interferência de Taunay, além do artigo já mencionado nesta nota, ver: BREFE, Ana Claudia Fonseca. O Museu Paulista: Affonso de Taunay e a memória nacional, 1917-1945. São Paulo: Editora Unesp; Museu Paulista, 2005. cap. 2. 
Bernardelli optou, então, pela realização de uma segunda versão. Há uma fotografia no arquivo do museu em que o pintor se fez retratar, empunhando palheta e pincéis, à frente do quadro, então em fase de elaboração (Fig.6). 0 bandeirante segura a arma na mesma posição utilizada por Calixto ao representar Domingos Jorge Velho, mas sua mão direita sustenta um cachimbo na boca. A fotografia revela ainda os riscos na tela que já esboçavam a inclusão de índios e de um segundo bandeirante que integrariam a narrativa da composição. Taunay escreveu a Bernardelli em julho de 1922 reagindo contra o cachimbo e a posição despreocupada, ociosa e anti-heróica do bandeirante Matias Cardoso de Almeida, sobrinho de Fernão Dias:

...como este quadro vai figurar numa galeria em que todos tem atitudes heróicas, não será de recear que ele venha representando um homem numa situação despreocupada como quem está a fumar? Receio que daí nasça uma certa heterogeneidade com os demais quadros e estátuas. Assim lhe pediria que suprimisse 0 cachimbo. 0 seu quadro deve ir ao lado da estátua do seu irmão que representa Pedro I a arrancar o tópico português. Ora, poderá causar estranheza ver-se um homem figura principal da tela, a fumar entre o Imperador nesta atitude heróica e o conquistador de Goiás estátua de Zani apoiado no seu arcabuz em posição de combate; não pensa assim? ${ }^{49}$

Taunay solicitou ainda a inclusão de barbas na figura do bandeirante, o que Bernardelli apenas insinuou. Mas o braço esquerdo foi retificado entre julho e setembro, a tempo do envio para São Paulo. 0 cachimbo desapareceu e o braço, flexionado, foi apoiado na cintura. Reaparecia assim a pose monárquica, muito embora, antes disso, o quadro de Calixto já devesse constituir um referencial importante para Taunay e, por seu intermédio, também para Bernardelli.

A Pinacoteca do Estado possui em seu acervo um estudo de Bernardelli em que o bandeirante já era retratado com a mão esquerda na cintura e o braço flexionado. No entanto, nesse estudo o pintor ainda manifestava indecisão quanto ao braço direito (Fig.7). Em traço mais forte, o braço foi representado estendido junto ao corpo, segurando um chicote, ou rebenque, pendente. A solução final adotada na tela a óleo - o braço estendido para o

49 MUSEU PAULISTA. SVDHICO. Carta de Affonso de Taunay a Henrique Bernardelli, 20 jul. 1922. A carta foi reproduzida integralmente em CHRISTO, Maraliz de Castro Vieira. Bandeirantes na contramão da História: um estudo iconográfico. Projeto História, São Paulo, 24, p. 313-314, jun. 2002. 
lado apoiado na arma de cano longo - está insinuada em traço fino, quase apagado ${ }^{50}$.

Um estudo de Bernadelli a óleo pertencente ao Museu Paulista evidencia a mesma indecisão (Fig. 8). A figura do bandeirante segue os traços fortes presentes no estudo em papel mencionado acima, pois o rebenque está presente, assim como o braço apoiado na cintura. Sua composição geral não é próxima à da tela de 1922, pois o ambiente compõe-se de uma clareira em meio à floresta tropical úmida.

A pose presente neste estudo, assim como a que está em traços fortes no estudo em papel, não serão adotadas na versão final, que segue a pose de Rigaud e de Calixto. Bernardelli certamente não compartilhava de uma visão tão rígida para a figuração do protagonista da tela, visto que, como lembra Maraliz Christo, suas obras evitavam qualquer alusão heróica aos bandeirantes em sua composição formal. Tanto na tela pioneira de 1889, Os bandeirantes, quanto no estudo Últimos momentos de um bandeirante, de 1932, em que figura um sertanista morrendo numa rede, guardado apenas por seu cão, Bernardelli esquivou-se de uma interpretação heróica dos antigos paulistas ${ }^{51}$.

$\mathrm{Na}$ mesma escadaria formal em que o painel de Bernardelli foi disposto em 1922, Taunay também implantou seis esculturas de bronze dedicadas à representação de bandeirantes, constituindo uma espécie de guarda de honra da escultura de Pedro I, posicionada no nicho central. Duas delas, dedicadas a Manuel Preto e Manuel da Borba Gato, seguem a mesma pose de inspiração francesa, retomada por Calixto. A escultura do italiano Nicola Rollo $^{52}$ - Manuel da Borba Gato - segue quase exatamente a figuração de Domingos Jorge Velho (Fig. 9). Por certo há a ausência do chapéu, de uma pistola e da espada posterior ao corpo, além da mão direita que surge por debaixo do manto. Mas o todo remete enfaticamente à tela de Calixto.

A escultura Manuel Preto, do belga Adrian Henri Vital van Emelen ${ }^{53}$, apresenta a mesma pose, mas com indumentária di-

50 Estudo em carvão, grafite e nanquim sobre papel. Doação do artista, 1937. Acervo da Pinacoteca do Estado, São Paulo.

51 Sobre Últimos momentos de um bandeirante e o apego de Bernardelli à figuração não heróica dos bandeirantes, ver, CHRISTO, Maraliz de Castro Vieira. Bandeirantes na contramão da História: um estudo iconográfico. Projeto História, São Paulo, 24, p. 320-324, jun. 2002.

52 Nicola Rollo, italiano, participou de vários concursos para monumentos escultóricos, atuando em obras públicas de grande envergadura da capital paulista, como a decoração escultórica do Palácio das Indústrias, e na realização de jazigos como o do meastro Chiafarelli, situado no cemitério da Consolação.

53 Van Emelen, nascido na Bélgica, foi pintor e escultor, tendo realizado um amplo conjunto de esculturas para a igreja beneditina de São Paulo. 
ferente (Fig. 10). Um gibão pespontado cobre o tronco, as coxas e o início dos braços. Não há a presença do manto. Nesta escultura, porém, o chapéu de abas largas reaparece.

Luigi Brizzolara ${ }^{54}$ foi responsável pela criação de duas esculturas monumentais em mármore de Carrara, concluídas em Gênova em 1922. Estão posicionadas nas paredes laterais do grande peristilo do museu, que antecede a escadaria e se comunica com as duas alas térreas. Dedicadas a Raposo Tavares e a Fernão Dias Paes Leme, estas esculturas recebem o visitante e preparam-no para suas semelhantes em bronze, as seis esculturas menores posicionadas nas paredes da escadaria. Fernão Dias Paes Leme - governador das esmeraldas (Fig. 11) foi concebida mantendo-se parcialmente a pose monárquica. 0 braço direito está apoiado na arma, enquanto o esquerdo levanta aos olhos do bandeirante a suposta esmeralda que ambicionava ter encontrado.

Estas esculturas e pinturas formam um eco de reciprocidades no Museu Paulista, facilitando a apreensão da figuração heróica e imponente dos sertanistas pelos visitantes. A intenção pedagógica do projeto decorativo e museal de Taunay tinha mais chance de êxito se as representações fossem replicadas pelo prédio. Para tanto, jamais poderia ele tolerar que uma das figurações posasse na tranqüilidade intimista e ociosa do ato de fumar um cachimbo. A mensagem heróica, de dimensão pública e de projeção perpétua, a ser internalizada pelos visitantes, paulistas e brasileiros, deveria ser alcançada mediante o zeloso controle das imagens.

0 sucesso da apropriação da pose monárquica por Benedito Calixto e, posteriormente, por Bernardelli, van Emelen e Rollo pode ser constatado em novas apropriações desta solução pictórica ao longo do século XX. Livros ilustrados por desenhistas (Fig. 12) ou louças comemorativas do IV Centenário de São Paulo (Fig.13) foram alguns dos numerosos suportes da representação de bandeirantes, segundo o padrão consolidado por Rigaud e retomado pelos artistas ligados ao Museu Paulista. Estas novas apropriações testemunham a ampla difusão dos bandeirantes em pose monárquica em diferentes veículos e segmentos sociais. Revela-se assim o alcance e a eficácia da reinvenção de Calixto, que plasmou a antiga pose dos Luíses de França nas figurações do heroísmo atribuído ao sertanismo paulista. A lição das coisas estava, portanto, aprendida.

54 Luigi Brizzolara, nascido e falecido na Itália, realizou, na capital paulista, o conjunto escultórico em homenagem a Carlos Gomes, inaugurado no vale do Anhangabaú em 1922, além do Monumento ao Anhangüera, escultura em carrara semelhante às esculturas do Museu Paulista, inaugurado em 1924 no Parque Siqueira Campos. 
Figura 1 - Hyacinthe Rigaud. Luís XIV em armadura, 1694, óleo s/ tela, 238 x $149 \mathrm{~cm}$. Acervo do Museo Nacional del Prado, Madri.

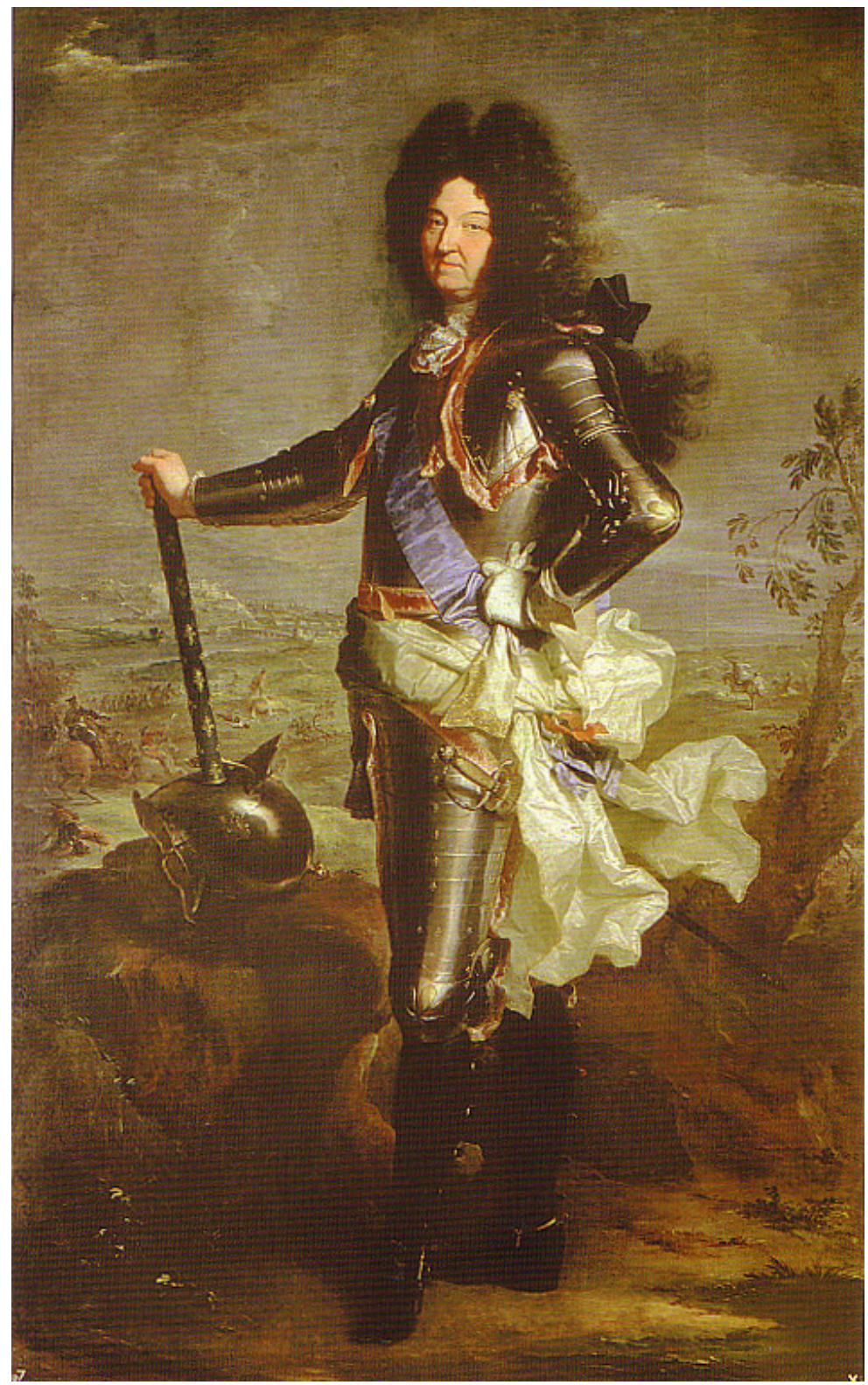


Figura 2 - Hyacinthe Rigaud. Luis XIV em indumentária real, 1701, óleo s/ tela, 277 x $194 \mathrm{~cm}$. Acervo do Musée du Louvre, Paris. Photo RMN $\odot$ Gérard Blot.

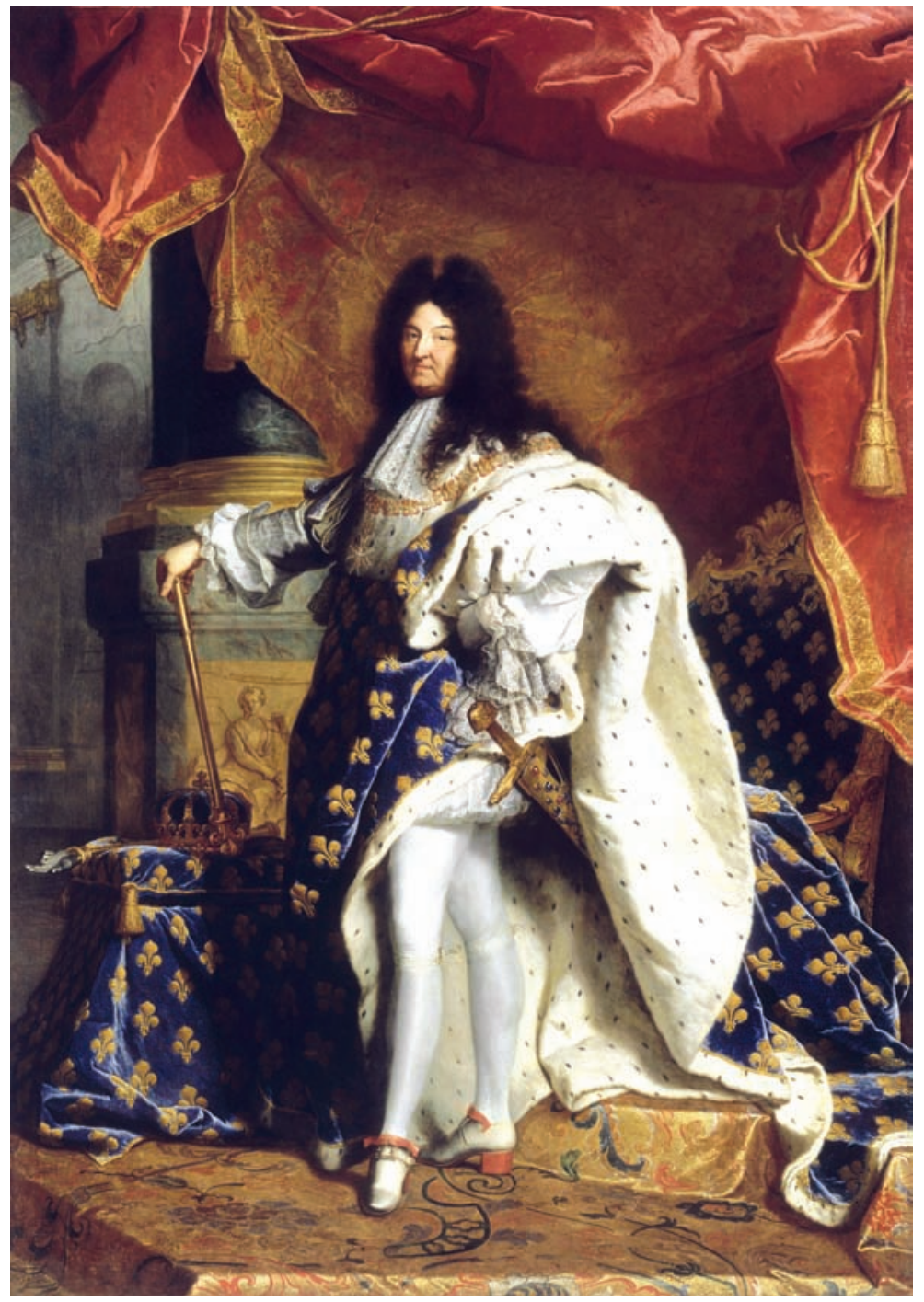


Figura 3 - Jean-Baptiste Debret. D. João VI, 1817, óleo s/ tela, $60 \mathrm{x}$ $42 \mathrm{~cm}$. Acervo do Museu Nacional de Belas Artes / IPHAN / MinC, Rio de Janeiro.

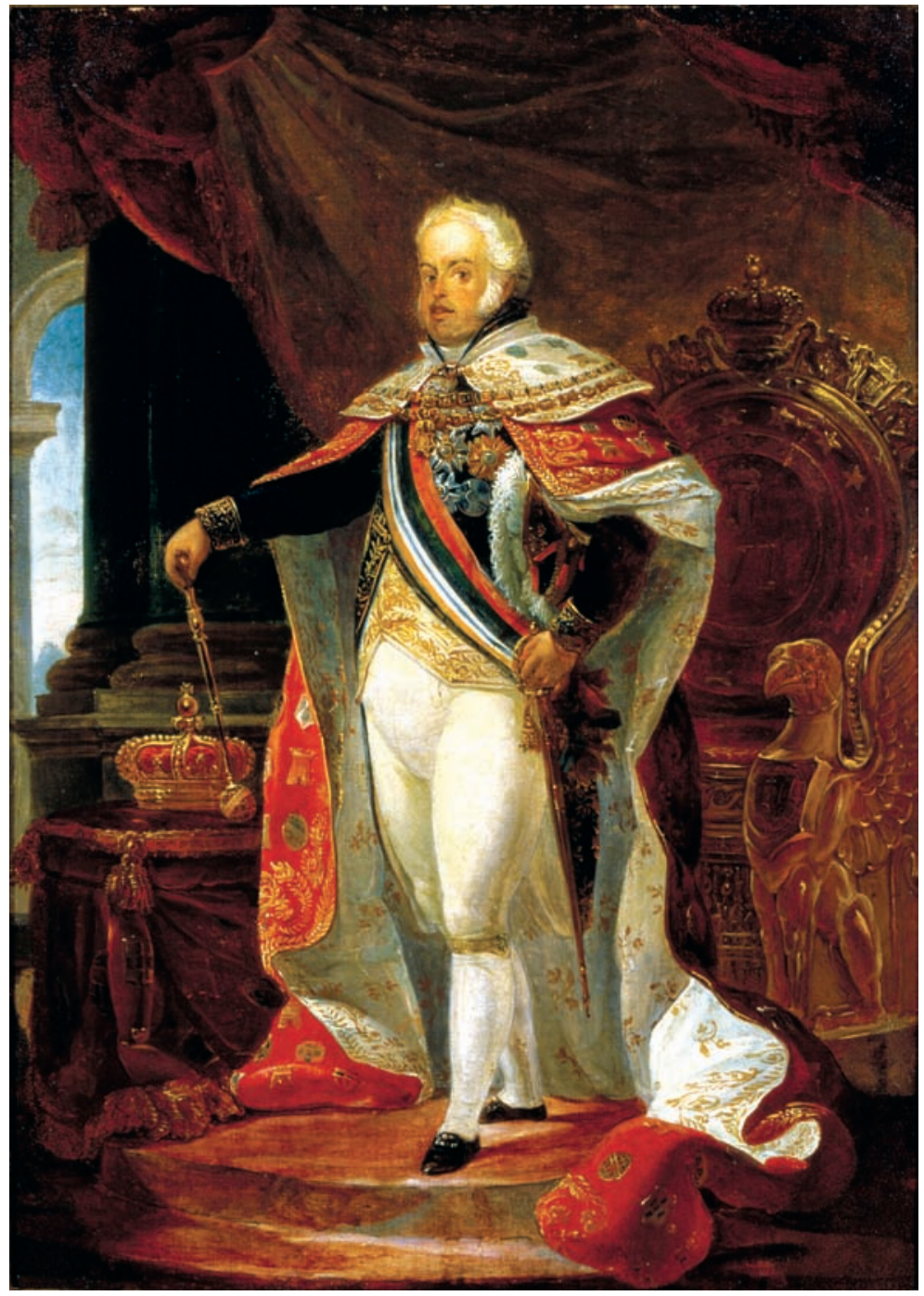


Figura 4 - Benedito Calixto. Domingos Jorge Velho e o loco-tenente Antônio Fernandes de Abreu, 1903, óleo s/ tela, 140 x $99 \mathrm{~cm}$. Acervo do Museu Paulista da USP, São Paulo. Reprodução de Hélio Nobre.

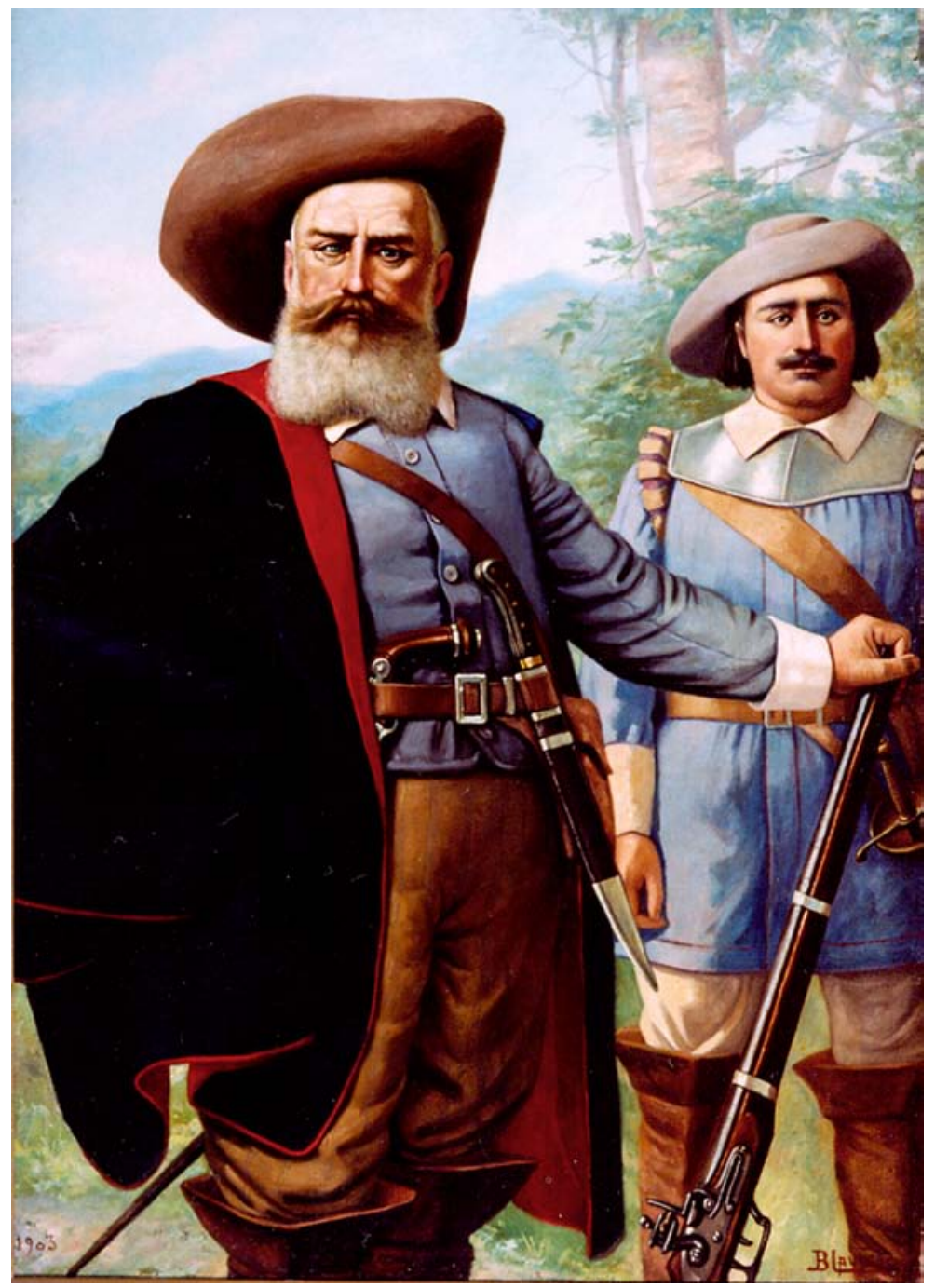


Figura 5 - Henrique Bernardelli. Ciclo da caça ao índio, 1923, óleo s/ tela. Acervo do Museu Paulista da USP, São Paulo. Reprodução de Hélio Nobre.

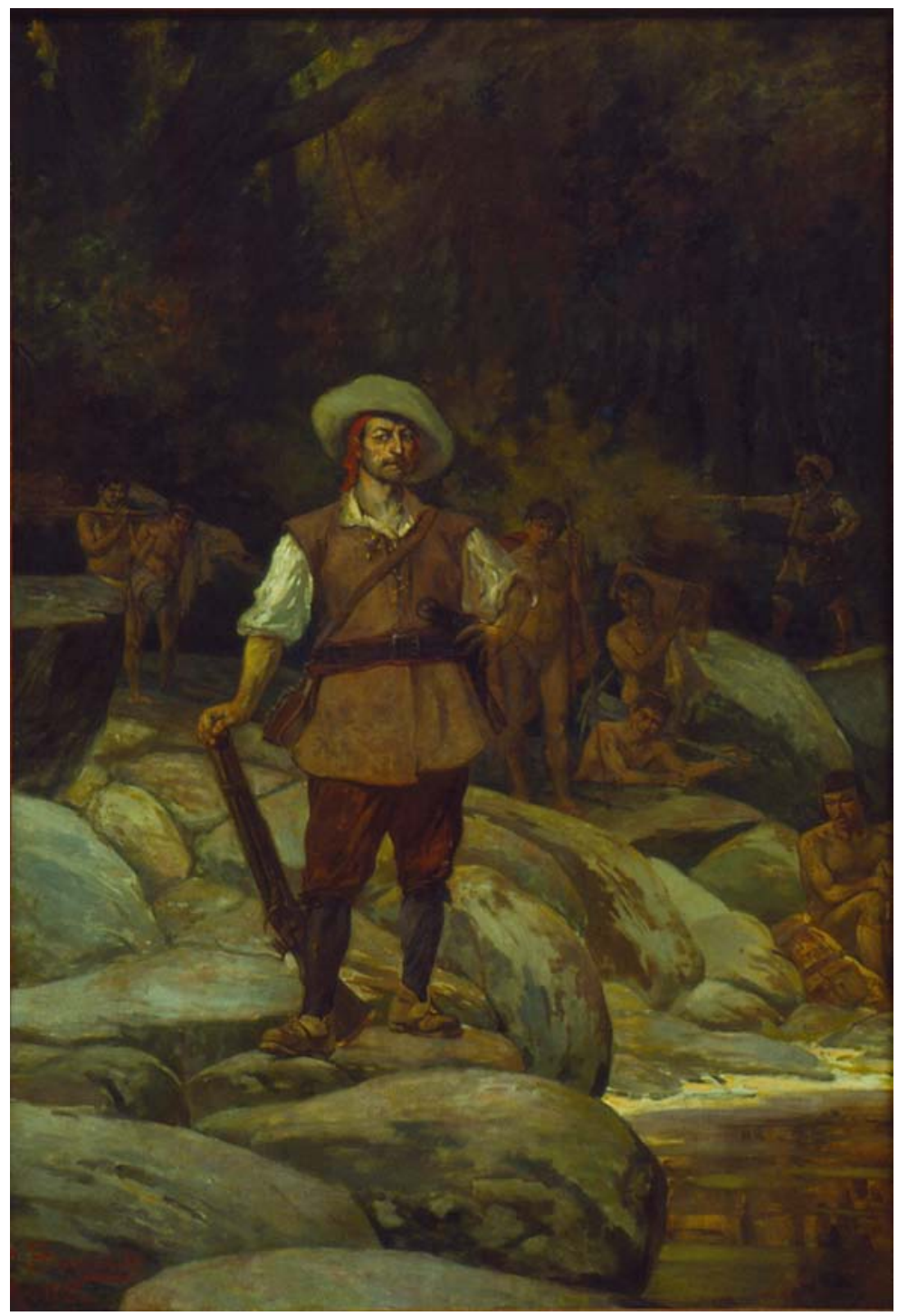


Figura 6 - Anônimo. Henrique Bernardelli no ateliê pintando Ciclo da caça ao índio, fotografia (cartão postal), $13,8 \times 8,8 \mathrm{~cm}$. Acervo do Museu Paulista da USP, São Paulo. Reprodução de Ana Carla Luiz.

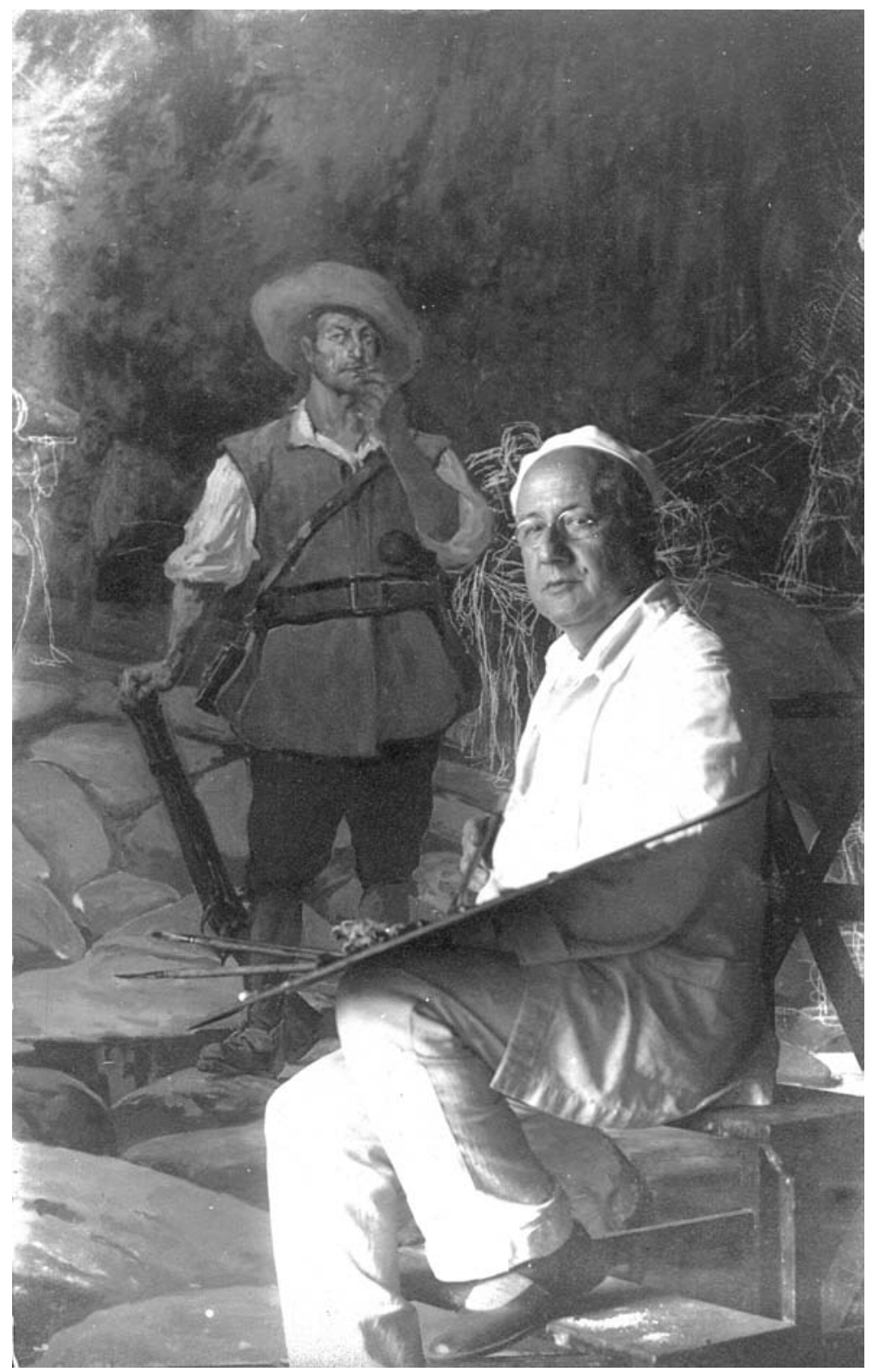


Figura 7 - Henrique Barnardelli. Estudo de Ciclo da caça ao índio, sem data, desenho a carvão e grafite s/ cartão, 59,4 x 43,5 cm. Acervo da Pinacoteca do Estado de São Paulo, São Paulo (Doação Espólio Henrique Bernadelli, 1937). Reprodução de Hélio Nobre.

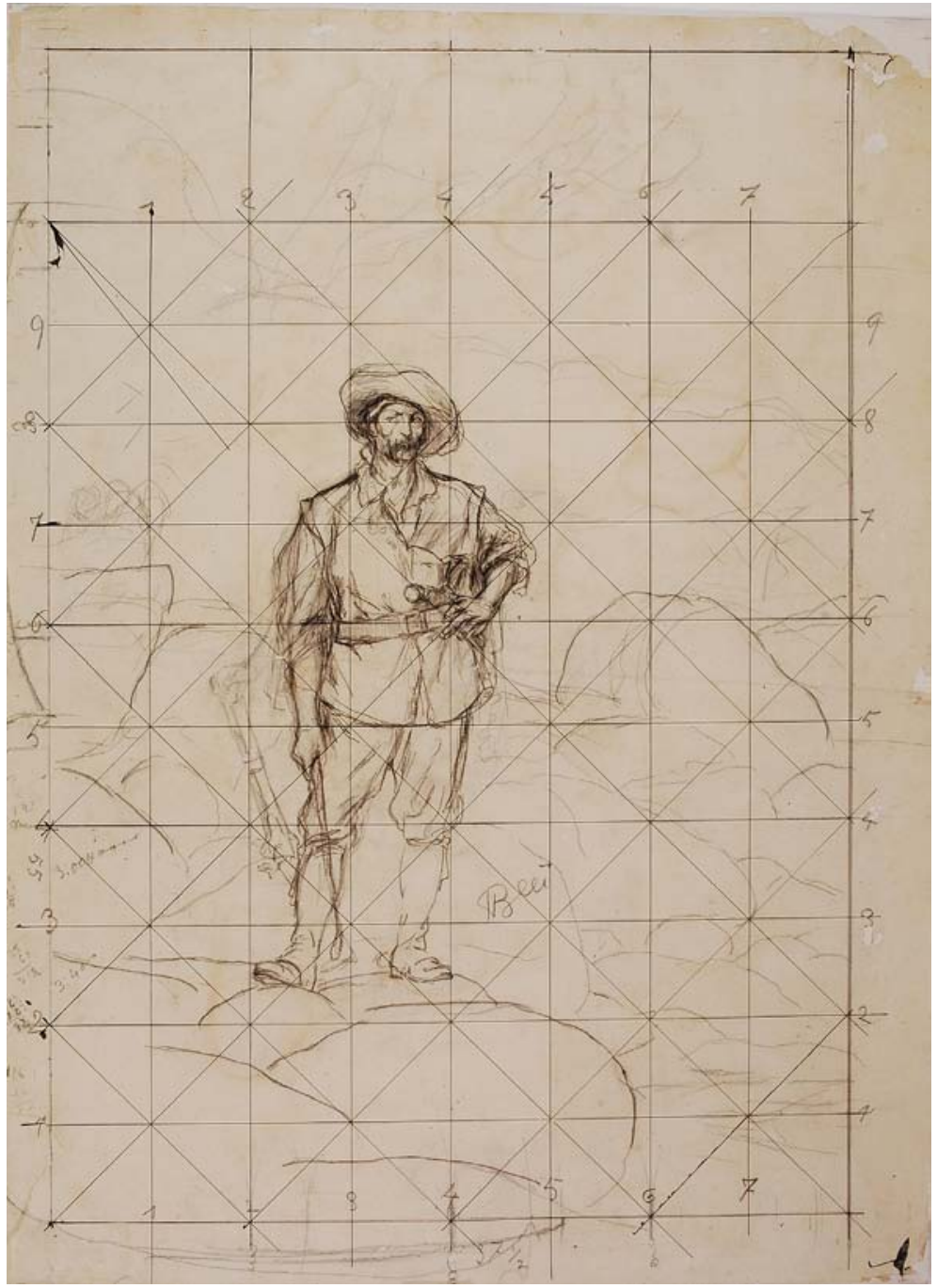


Figura 8 - Henrique Bernardelli. Estudo de Ciclo da caça ao índio (Bandeirante na selva), sem data, óleo s/ tela, 56,50 x 38,50 cm. Acervo do Museu Paulista da Universidade de São Paulo, São Paulo. Reprodução de Hélio Nobre.

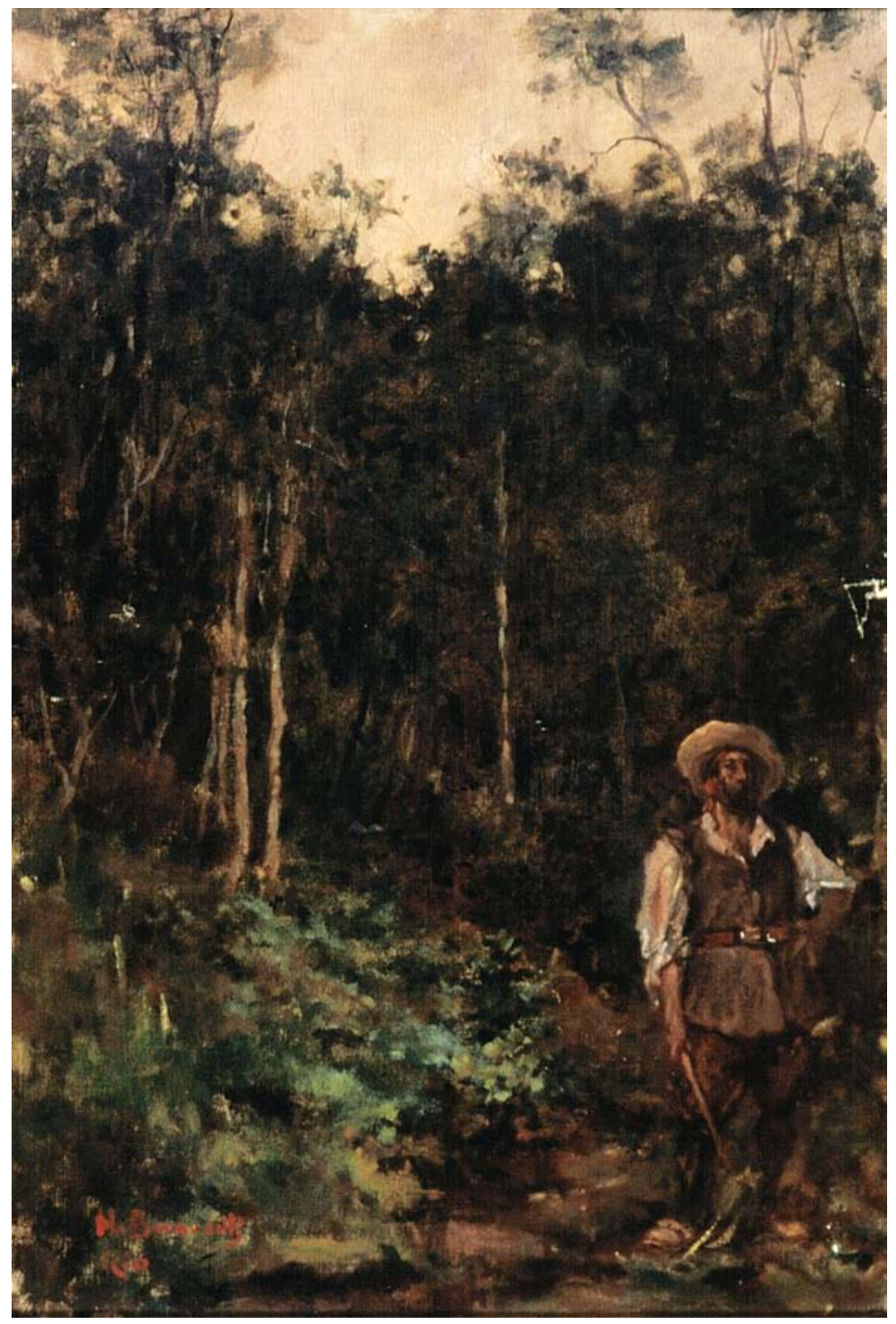


Figura 9 - Nicola Rollo. Manuel de Borba Gato, 1921, bronze. Acervo do Museu Paulista da Universidade de São Paulo, São Paulo. Reprodução de Hélio Nobre.

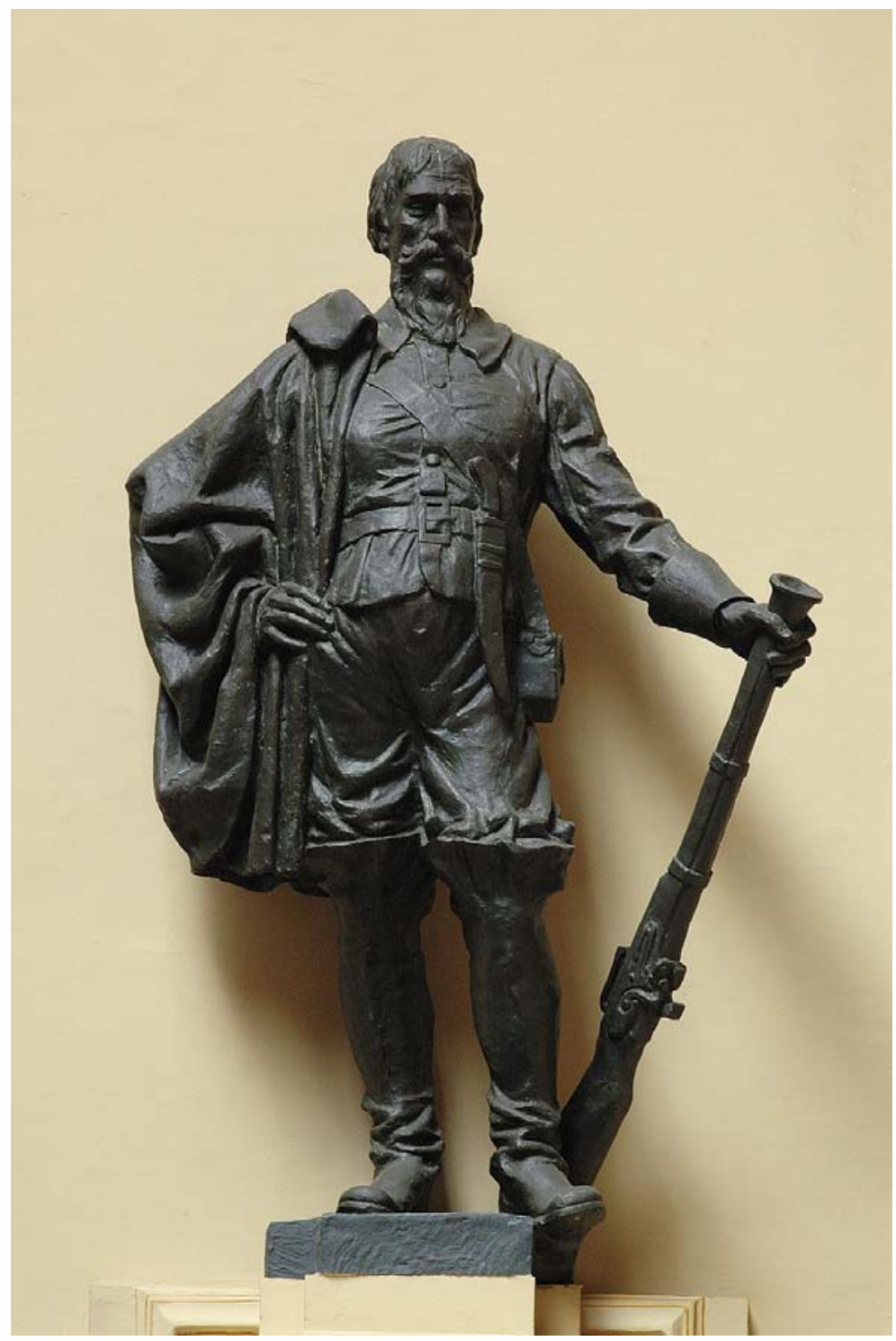


Figura 10 - Adrian Henri Vital van Emelen. Manuel Preto, 1921, bronze. Acervo do Museu Paulista da Universidade de São Paulo, São Paulo. Reprodução de Hélio Nobre.

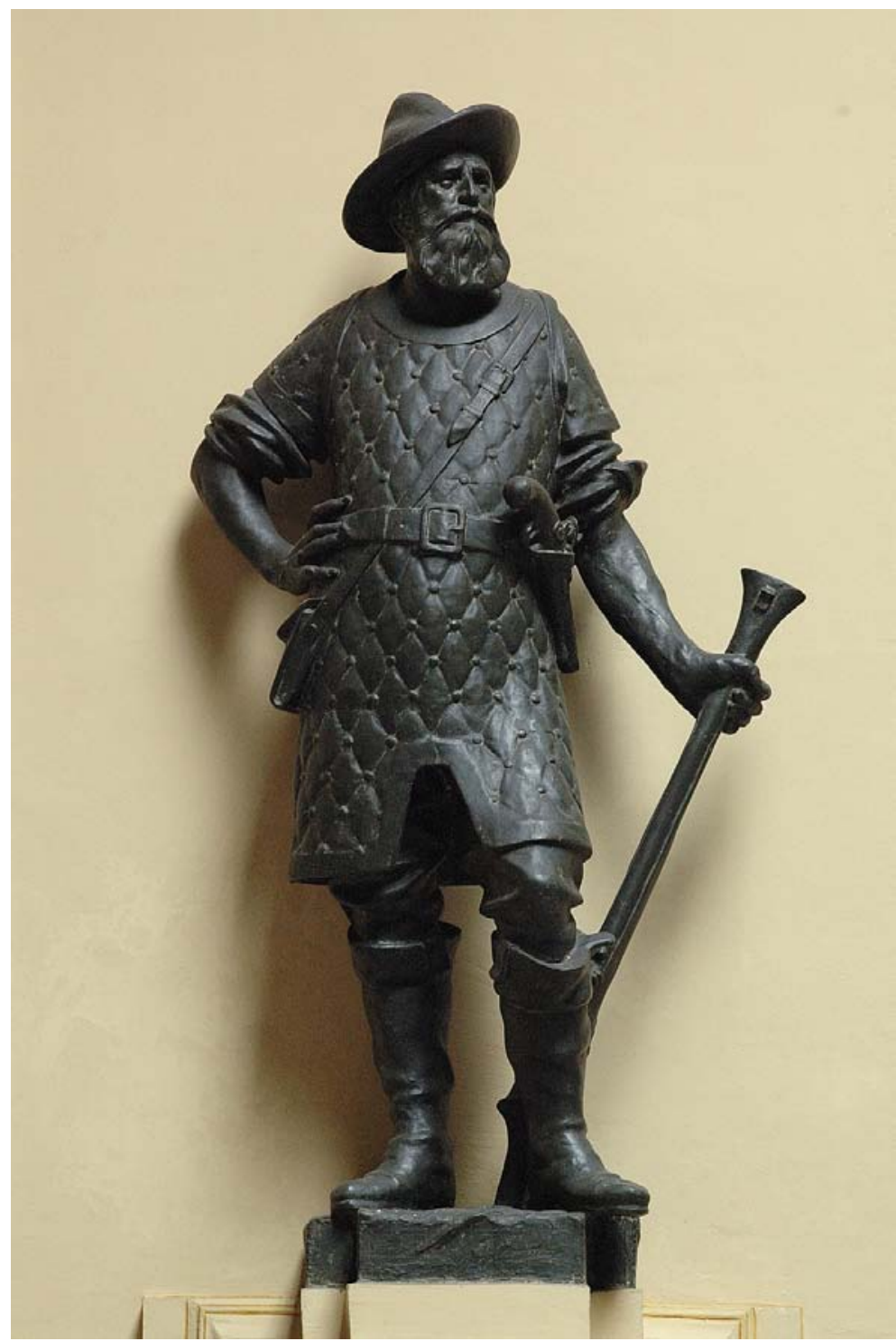


Figura 11 - Luigi Brizzolara.Fernão Dias Paes Leme - governador das esmeraldas, 1922, mármore de Carrara, $153 \times 370 \mathrm{~cm}$. Acervo do Museu Paulista da Universidade de São Paulo, São Paulo. Reprodução de José Rosael.

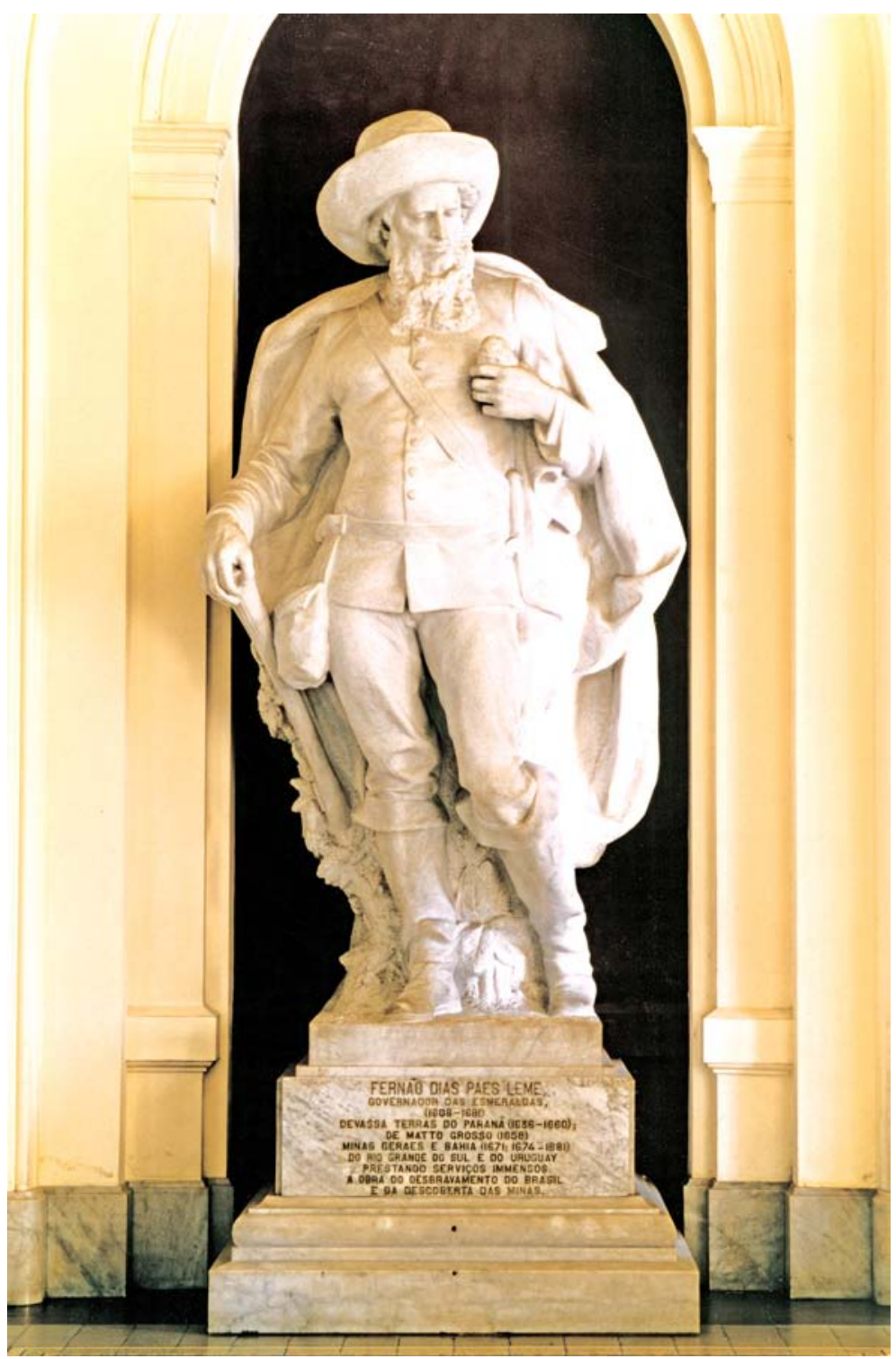


Figura 12 - Oswaldo Storni. Ilustração do livro Fernão Dias Pais - o governador das esmeraldas, de Barros Ferreira, Edições Melhoramentos, década de 1940, impresso, 19,2 x 16,8 cm. Acervo do Museu Paulista da Universidade de São Paulo, São Paulo. Reprodução de Hélio Nobre.

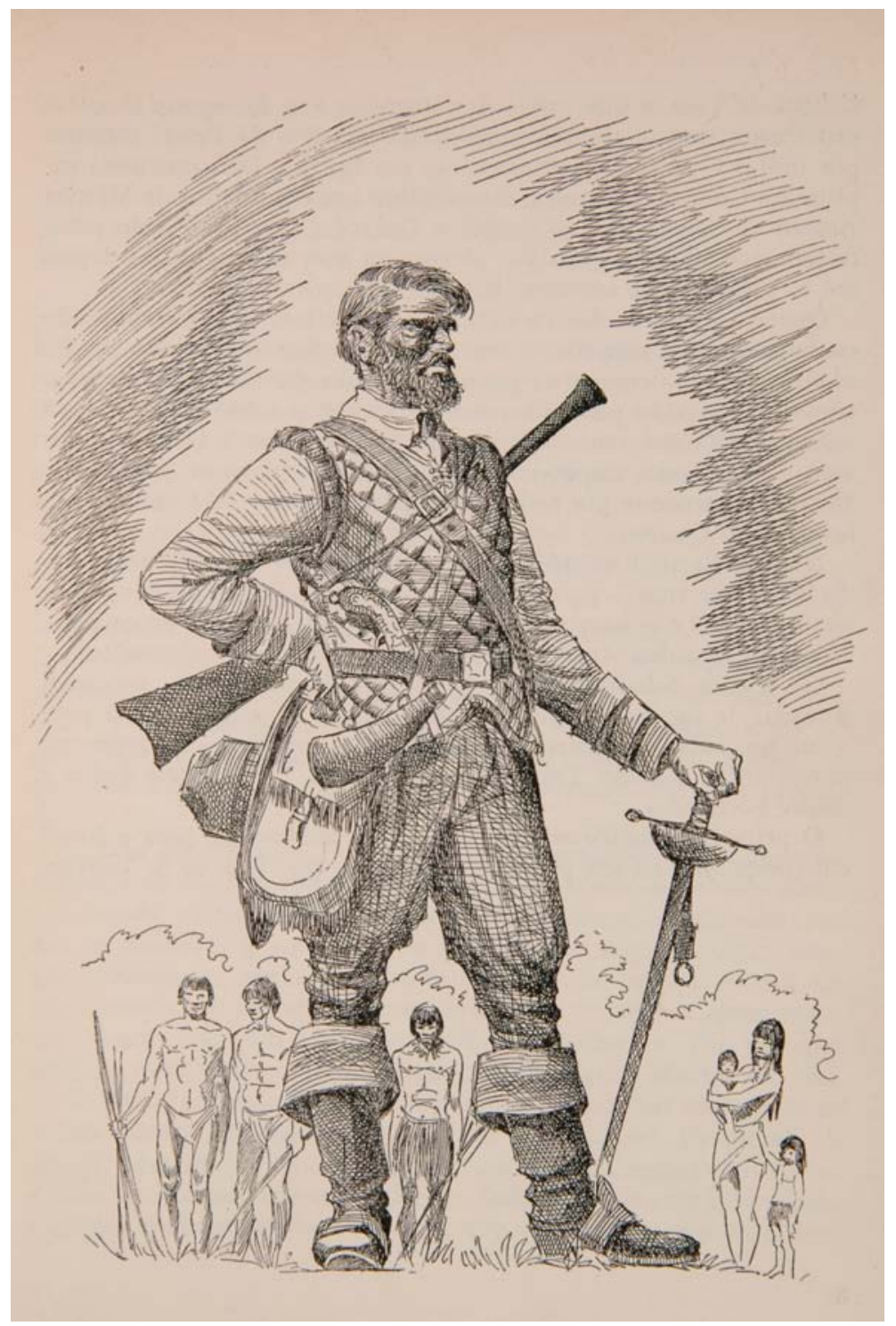


Figura 13 - Porcelana Real S/A. Vaso comemorativo do $4^{\circ}$ Centenário da cidade de São Paulo, c.1954, porcelana, $25 \times 12 \mathrm{~cm}$. Acervo do Museu Paulista da Universidade de São Paulo, São Paulo. Reprodução de José Rosael.

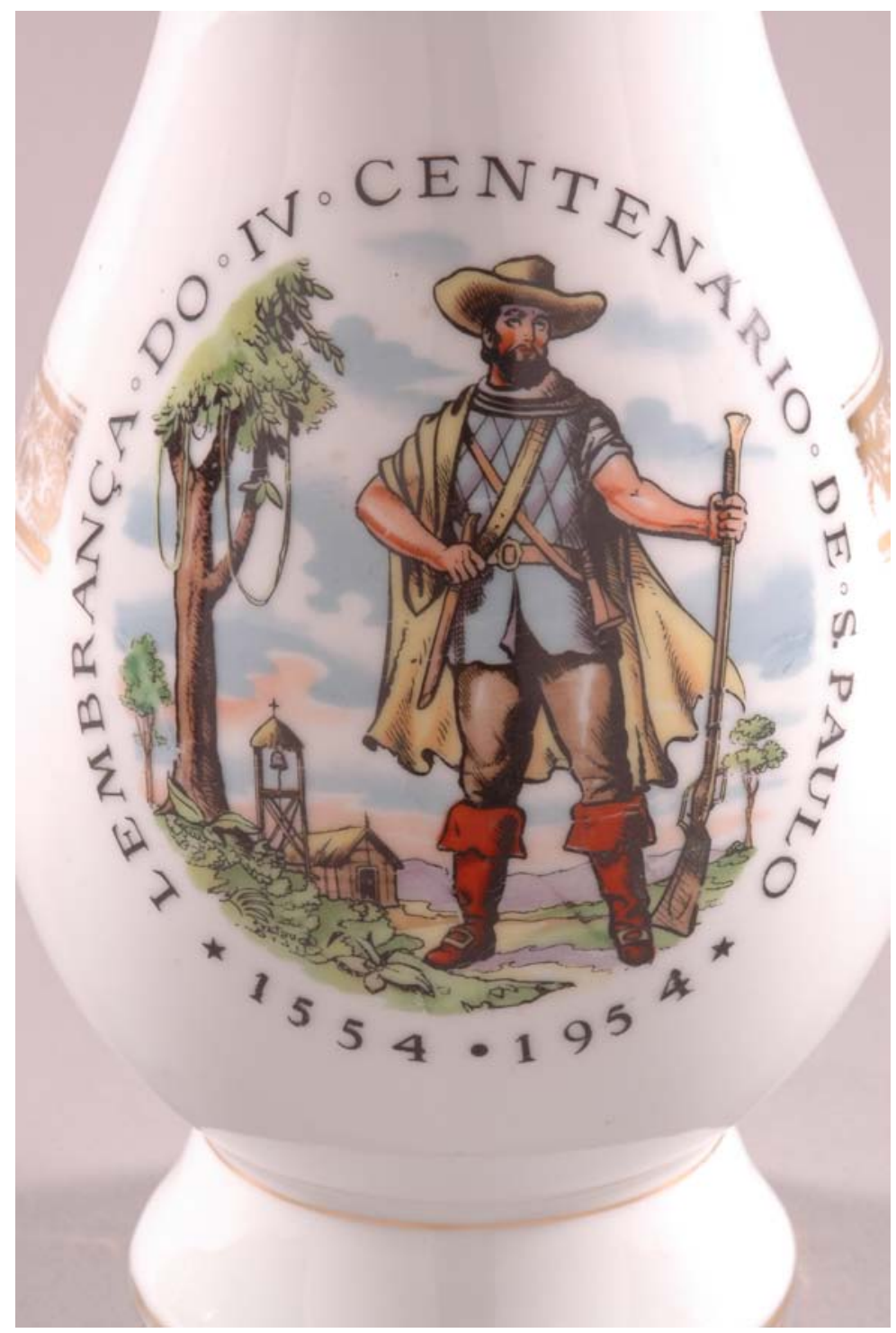

